\title{
ČLÁNKY
}

\section{Práva z vad při smíšeném darování}

\section{Remedies for Nonconformance of Performance in Terms of Mixed Sale with Donation}

\author{
Viktor Kolmačka*
}

\begin{abstract}
Abstrakt
Predmètem článku je problematika práv z vad v prípadě smišenébo darování. Tento drub prostredkù nápravy predpokládá úplatnou povahu smlouvy, a proto bude nejprve osvètlen význam úplatnosti. Poté je pozornost vènována rozboru jak pristupovat k závazku, který má charakter smísenébo darování, nebot' současná česká nauka toto téma neobjasñuje. Koněnè tento článek usiluje o nabídnutí rèsení, za jakých predpokladio odpovidá zcizitel za vady svého plnèni a jakým zpuisobem maji být práva z. vad realizována.
\end{abstract}

\section{Klíčová slova}

Smišsené darování; odpovědnost za vady; primèrené sniženi ceny; odstoupeni od smlouvy; odstranèni vady.

\begin{abstract}
This article focuses on remedies for nonconformance of the performance in terms of the mixed sale with donation. This type of remedies posits an onerous character of the contract, therefore, the paper explains firstly the meaning of this requirement. The next part is dedicated to an analysis of how to approach the partly onerous and partly lucrative agreement, as the current Czech literature does not consider the issue. Finally, the article aims to propose a solution to, under which circumstances the seller (donor) is liable for nonconformity of his performance and how the remedies should be realized.
\end{abstract}

\section{Keywords}

Mixed Sale with Donation; Remedies for Nonconformance; Price Reduction; Avoidance; Remedy of Repair.

\section{Úvod}

Předkládaný př́íspěvek se zabývá otázkou, za jakých předpokladů a v jaké míre jsou realizovatelná práva z vad v př́padě tzv. smíšeného darování (k pojmu srov. 2).

Problematice smíšeného darování byla českou civilistikou doposud věnována zcela marginální pozornost. Naproti tomu v námi prríbuzných právních rádech jsou problematické otázky aplikace ustanovení, které zpravidla předpokládají bud’ prostou bezúplatnost,

\footnotetext{
* Mgr. Viktor Kolmačka, doktorand a asistent, Katedra soukromého práva a civilního procesu, Právnická fakulta, Univerzita Palackého, Olomouc / Ph.D. Student and Assistant, Department of Private Law and Civil Procedure, Faculty of Law, Palacký University, Olomouc, Czech Republic / E-mail: viktor. kolmacka@upol.cz / Research ID: 57226775748
} 
či úplatnost, předmětem dlouhé a stále neutichající diskuze. Jak komplikované a na výsost sporné je a vždy bylo právní zacházení se smíšeným darováním, líčí část týkající se vývoje jednotlivých teorií a př́stupů, jež se snažily zdůvodnit jeho právní povahu (srov. 3). Bez reflektování a pochopení tohoto vývoje není otázka (perspektivní) odpovědnosti ${ }^{1}$ zcizitele za vady uspokojivě (a především srozumitelně) řešitelná. Teorie o právním zacházení se smlouvou, jež má částečně úplatnou a současně bezúplatnou povahu, přitom díky své vysoké abstraktnosti a „nadčasovosti““ umožňuje podrobit tuto otázku diskurzu např́íc více právních řádů, ač mezi nimi pochopitelně existují nemalé rozdíly. Aktuální závěry české nauky, vyslovené ve vztahu k zákonu č. 89/2012 Sb., občanskému zákoníku (dále jen „OZ"), ve své podstatě tento vývoj a diskuzi nereflektují. Ostatně, jak bude dále $\mathrm{v}$ textu vylíčeno, je patrno, že v české doktríně od dob prvorepublikové nauky lze sotva hovořit o nějakém posunu přri řešení otázek spojených se smíšeným darováním.

Tento prŕíspěvek se koncentruje na otázku prrípadné odpovědnosti zcizitele za vady, která představuje pouze dílčí skupinu problematických otázek spojených se smíšeným darováním. Názory české literatury se k tomuto problému vyslovují natolik lakonicky, že z nich nelze seznat ani konkretizovaný způsob, jak mají být jednotlivá práva z vad realizována (k tomu srov. 3.6). Níže předkládaná analýza dokládá, že samotné pochopení komplikovanosti této otázky si zasluhuje pojednání rozsáhlejší než jeden odstavec. ${ }^{2}$

Účelem předkládaného textu je především nabídnout právnědogmaticky zdůvodněné řešení těchto otázek:

1. Co je předpokladem nabyvatelových práv z vad v př́padě smíšeného darování a

2. v jaké míre jsou tato práva $\mathrm{v}$ daném závazku uplatnitelná?

Jakým způsobem má být uskutečněno:

3. právo na opravu,

4. právo na dodání toho, co chybí,

5. právo na přiměřené snížení ceny a konečně

6. právo na odstoupení od smlouvy?

Základní úvahy, na nichž předkládaná stat' staví své závěry, spočívají v ujasnění si smyslu a účelu práv z vadného plnění, a proto se věnuje úvodní pasáž teleologickému pozadí práv z vad. U smíšeného darování nastává kombinace úplatné a bezúplatné povahy závazkového poměru, prričemž právě aspekt úplatnosti tvoří předpoklad odpovědnosti za vady (\ 1914 an. OZ) a zrcadlově se odráží nejen v její existenci, nýbrž ve své podstatě též v míře jejího uplatnění. Z tohoto důvodu je problematice smíšeného darování předřazena část, která se zaobírá odlišením odpovědnosti zcizitele za vady u úplatného a bezúplatného závazku.

1 Dále se pojem odpovědnosti používá ve smyslu Haftung.

2 Takto ve své habilitační práci ELISCHER, David. Darování a jeho podoby v novém soukromém právu. Praha: Wolters Kluwer, 2016, s. 37. 
Práva $z$ vad jsou zde analyzována právě v kontextu smíšeného darování, a to s důrazem na problematické aspekty, jichž se smíšená povaha dotýká. Obecné otázky práv z vad, společné též s ,plně úplatnou“ smlouvou, nejsou předmětem zdejšího zájmu.

\section{1 Úplatnost jako conditio sine qua non odpovědnosti zcizitele za vady}

\subsection{Odpovědnost za vady jako prostředek nápravy narušené subjektivní ekvivalence ${ }^{3}$}

Obecná úprava práv z vad dle \1914 an. OZ stojí na myšlence, že povinnosti z vad, tj. povinnosti založené nikoliv řádným plněním, mohou stíhat jen toho, kdo plnil za úplatu. Skutečnost, že zcizitel odpovídá za vady věci, tedy za nesoulad plněného a toho, co plněno být mělo, je právě důsledkem subjektivní ekvivalence. ${ }^{4}$ Plnění jedné strany má totiž pro př́jemce právě takovou hodnotu, jakou se sám zavázal poskytnout a vice versa. Není proto rozhodující obvyklá cena plnění (tzv. objektivní ekvivalence), nýbrž cena odvozená z vưle stran: „Každé plnèni vytvář́ ekvivalent protiplnéni."

Jestliže jedna ze stran neposkytne to, co poskytnout měla (odchylka od smluvně ujednaného, dispozitivně určeného, či smluvně-dispozitivně určeného), ${ }^{6}$ tak plnění narušuje sjednanou ekvivalenci. ${ }^{7}$ Nástroj, který narušenou ekvivalenci vyrovnává, představují právě práva $\mathbf{z}$ vad. ${ }^{8}$

Nepřitakává se tak „mlhavé“ socialistické formuli, ${ }^{9}$ že práva z vad slouží k nápravě újmy způsobené vadným plněním. Vadné plnění stojí na jiných předpokladech než náhrada škody a nelze ho simplifikovat na význam saturace škody způsobené vadným plněním. ${ }^{10}$ Nesprávnost této teze ostatně tkví v tom, že jedním z práv z vadného plnění je odstoupení od smlouvy. Zmíněný prostředek žádnou újmu nenapravuje, nebot' slouží k vytvořné stavu, jaký zde byl před uzavřenou smlouvou. Naproti tomu je však způsobilý

3 Text sub 1.1 se v podstatné míře shoduje s pasáží sub II. in KOLMAČKA, Viktor. Přiměřené snížení ceny jako prostřredek nápravy narušené subjektivní ekvivalence. Právní roz̧bledy, roč. 29, č. 13-14, s. 457-458.

4 Srov. ROUČEK, František. Správa pro nedostatky skutkové. Praha: Nákladem vlastním, 1923, s. 12.

5 Takto WEIRAUCH. Die gemischte Shenkung. In: GRUCHOT, J. A. Beiträge zur Erläuterung des deutschen Rechts. Hamm: Grote, Band 48, 1904, s. 232.

6 Této myšlence odpovídá tzv. subjektivně, objektivně, či též subjektivně-objektivně vadný pojem (reprezentativně v něm. nauce GREINER, Stefan. Schuldrecht Besonderer Teil: Vertragliche Schuldverhältnisse. 2. vyd. Berlin-Heidelberg: Springer 2019, \ 2 marg. č. 51 an.; v rak. GRUBER, Michael. Gewährleistung für bedungene Eigenschaften. Wien: Verlag der Österreichischen Staatsdruckerei, 1990, s. 32-33, marg. č. 8, 9).

7 Slovy brněnské normativní školy se svět „,byti““ rozchází se světem „mětí“.

8 Srov. WELSER, Rudolf a Brigitta ZÖCHLING-JUD. Bürgerliches Recht II. 14. vyd. Wien: MANZ, 2015, marg. č. 305; ze starší nauky kup̌r. WINIWARTER, Joseph von. Das österreichische bürgerliche Recht. IV. Theil. 2. rozšířené a vylepšené vyd. Wien: Braumüller und Seidel, 1844, s. 85; z novější např. KREJCI, Heinz. Reform des Gewährleistungsrechtes. Verlag Österreich, 1994, s. 9.

9 Viz LAZAR, Ján a Jiři ŠVESTKA. Občanské právo bmotné. 2. Praha: Panorama, 1987, s. 240-241.

$10 \mathrm{~V}$ bližších podrobnostech srov. KOLMAČKA, Viktor. Přiměřené snížení ceny jako prostředek nápravy narušené subjektivní ekvivalence. Právni roz̧hledy. roč. 29, č. 13-14, s. 459 a násl., sub IV, V. 
napravit narušenou ekvivalenci tím, že nabyvatel si smí ponechat protiplnění, v důsledku čehož není nucen přijmout neekvivalentní plnění ve smyslu subjektivní ekvivalence, příp. je oprávněn požadovat vrácení toho, co plnil.

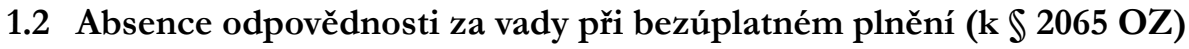

Skutečnost, že práva z vad vedou k napravení narušené ekvivalence, by měla být zákonitě promítnuta do interpretace $\int 2065$ OZ, který stanoví zvláštní pravidla odpovědnosti dárce vůči obdarovanému, neodpovídá-li předmět daru darovací smlouvě.

Z úvah podaných sub 1.1 jednoznačně plyne, že tam, kde bylo plněno bezúplatně, nemohou mít práva z vad místo. Je tomu tak proto, že dárce plní bez protiplnění. ${ }^{11}$ Kauzou smluvní obligace není směna (tj. causa adquirendi), nýbrž causa donandi. Zda účel darování, spočívající v radosti dárce, v potěšení či odměně obdarovaného za určité chování, je právně irelevantní pohnutkou, nebo součástí kauzy, ${ }^{12}$ se zde ponechává otevřené. O subjektivní ekvivalenci však pro absenci kauzy adquirendi nemůže být řeč, a tím pádem práva z vad, které slouží k narovnání narušené ekvivalence, nelze per definitionem použít. Ač tento přístup může zavánět pojmovou jurisprudencí, pak z hlediska otázky odpovědnosti za vady u smíšeného darování jde o klíčový poznatek, na kterém stojí dále podané úvahy sub 4 an. Nesoulad darovaného předmětu s obsahem darovací smlouvy tak práva $z$ vad ve smyslu \} 1 9 1 4 \text { an. OZ nezakládá, a proto \2065 OZ není vhodné označovat jako následek vad- } ného plnění ve smyslu odpovědnosti dárce za vady daru. ${ }^{13,14}$ Obdarovaný nemůže žádat

11 Výmluvně, ač formálně logicky, hovoři Rouček o tom, že „správa jako odstraněni damni in re (oproti damnum ex re) je myslitelná jen za predpokladu t. zv. aequivalentu t.j. toliko prí právním jednání úplatném. Zvètš-li se právní sféra osoby jednáním bezplatným o nějakou věc s vadami $(V-v=V 1)$, nelze mluviti o porušeni status quo v prenechané věci $[. .$.$] Tu právě trvá jen status quo, nabyvatel postrádá titulu na rozmnoženi svébo jmèní, a netrvá-li status quo,$ neni to následkem damni in re, nýbrž damni ex re. Ochrana soukromoprávního styku je jako konečný účel instituce správy myslitelnou pouze pri jednáni úplatném. "Viz ROUČEK, František. Správa pro nedostatky skutkové. Praha: Nákladem vlastním, 1923, s. 16.

12 Flume uvádí, že se při bezúplatných jednání musí každý vážný projev o důvodu poskytnutí majetkové výhody (Zuwendung) přičítat kauze právního jednání. Vyjadřuje-li tak dar „odměnu“ obdarovanému za určité vykonané jednání (např. záchrana tonoucího dárce), přičemž vyjde najevo, že obdarovaný toto jednání neučinil, pak právní jednání postrádá kauzu. $\mathrm{V}$ takovém př́padě pak může dárce prostřednictvím condictio indebiti požadovat plněný dar (Srov. FLUME, Werner. Allgemeiner Teil des Bürgerlichen Rechts. Band 2. Das Rechtsgeschäft. 4., nezměněné vyd. Berlin, Heidelberg, New York, London, Paris, Tokyo, Hong Kong, Barcelona, Budapest: Springer, 1992, s. 172).

13 Takto ale JANOUŠEK, Michal. In: PETROV, Jan et al. Ob̌́anský qákoník: komentár. Praha: C. H. Beck, 2017, \ 2066, marg. č. 2.

14 Srov. již WINIWARTER, Joseph von. Das österreichische bürgerliche Recht. IV. Theil. 2. rozšírené a vylepšené vyd. Wien: Braumüller und Seidel, 1844, s. 85: jde o odpovědnost rezultující z nepoctivosti dárce; navíc dárce neodpovídá za faktické vady. I Eisner zdůrazňuje, že jednak jde o odpovědnost za dolus, jednak o zvláštní dle smlouvy převzatý závazek, který se posuzuje dle obecných zásad o smlouvách, nikoliv ustanovení o odpovědnosti za vady ve smyslu \ 922 až 933 zák. č. 946/1811, všeobecného občanského zákoníku pro všechny dědičné země rakouské monarchie, ve znění pozdějších předpisů, platného a účinného v Rakouské republice (dále jen „ABGB“), které jsou předlohou $\int 1914$ an. OZ ... 
ani opravu věci, ani dodání toho, co chybí a z povahy věci ani přiměřenou slevu z ceny. ${ }^{15}$ Označení odpovědnosti za vady tak v tomto ohledu působí matoucím dojmem. Dárce zůstává pouze omezen na nárok na náhradu škody, event. může požadovat odstoupení od smlouvy, čímž však k žádnému vyrovnání ekvivalence nedochází.

Ustanovení \2065 OZ představuje výraz principu utility. ${ }^{16}$ Tato zásada staví na myšlence, že ten, kdo plní bezúplatně, nemá odpovídat za škodu ve stejně přísném režimu jako ten, kdo plní za úplatu (ti. dle \2913 OZ). Citované ustanovení však omezení odpovědnosti vztahuje toliko $\mathrm{k}$ povinnosti plnit řádně, tj. bez vad. Je třeba zdůraznit, že náhrada škody není ani v českém právním řádu chápána jako prostředek nápravy vadného plnění (srov. S 1925 OZ). Ustanovení \2065 v. 1 OZ zakládá povinnost nahradit škodu, která vznikla v důsledku vědomě porušené smluvní povinnosti plnit řádně. ${ }^{17}$ Protože o rozsahu náhrady škody rozhoduje druh porušené povinnosti (zde informační povinnost dárce nezatajit pravý stav věcî), pak nemůže vzniknout nárok na náhradu škody spočívající v tom, že obdarovaný nenabude předmět daru o hodnotě, který nabýt měl. Ochranný účel ${ }^{18}$ \ 2065 v. 1

...

(Viz EISNER, Berthold. Zur Lehre von der Gewährleistung nach österr. allg. Privatrechte. Grunbüts Zeitschrift, 1912, s. 586). Dle \945 ABGB platí, že ten, kdo vědomě daruje věc cizí a obdarovanému tuto okolnost zatají, ručí za škodlivé následky. V rakouské nauce přitom nepanuje jednota, zda leg. cit. zakládá odpovědnost dárce za právní vadu, nebo jde o právní normu měnící předpoklady nároku na náhradu škody. Stojí však mimo vši pochybnost, že ustanovení \922 an. ABGB nemohou najít uplatnění zastánce, že jde o odpovědnost za právní vadu, přičemž odpovědnost za škodu je tímto nedotčena: ERTL, Gunter. In: FENYVES, Attila, Ferdinand KERSCHNER, Andreas VONKILCH et al. Großkommentar zum ABGBKlang Kommentar. \} 9 3 8 \text { bis 1001. 3. vyd. Wien: Verl. Österreich, 2013, \ 945, marg. č. 5, který navazuje } na Koziola, podle něhož $\int 945$ ABGB snižuje objektivní povinnosti péče (Sorgfaltspflichten), při jejichž porušení se odpovídá za každé zavinění, přičemž leg. cit. nevede nikterak k ulehčení deliktní odpovědnosti (KOZIOL, Helmut. Österreichisches Haftpflichtrecht. Band I, Allgemeiner Teil. 4. vyd. Wien: Jan Sramek Verlag, 2020, s. 301, 911, C1, marg. č. 58, E, marg. č. 16); zastánce, že vědomé porušení smluvní povinnosti se má per analogiam zobecnit na všechny případy odpovědnosti dárce za škodu: STANZL, Gustav. In: KLANG, Heinrich, Franz GSCHNITZER et al. Kommentar zum Allgemeinen bürgerlichen Gesetz̧buch: Band 4,

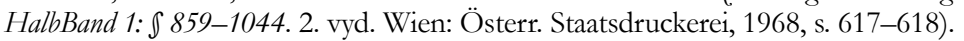

15 Shodně GSCHNITZER, Franz. In: GSCHNITZER, Franz, Heinrich KLANG et al. Kommentar zum Allgemeinen bürgerlichen Gesetzbuch. 4. Band. 1. Teilband. $\int$ 859-1044. 2. vyd. Wien: Österr. Staatsdruckerei, 1968, s. 502; shodně EISNER, Berthold. Zur Lehre von der Gewährleistung nach österr. allg. Privatrechte. Grunbüts Zeitschrift, 1912, s. 585 a násl.

16 Srov. LORENZ, Stephan a Dieter MEDICUS. Schuldrecht II Besonderer Teil. 18. vyd. München: C. H. Beck, 2018, \1, marg. č. 5, 6. Podobně i někteří rakouští autoři o \945 ABGB uvádějí, že má ulehčit odpovědnosti dárce, viz poznámka pod čarou č. 15.

17 Viz NIPPEL, Franz Xaver. Erläuterung des allgemeinen bürgerlichen Gesetzbuches für die gesamten deutschen Länder der österreichisschen Monarchie, mit besonderer Berücksichtigung des pract. Bedürfnisses. VI Band. $\int 859$ bis einschließig 982. Grätz: Damian und Sorge, 1833, s. 229.

18 Někdy bývá stírán rozdíl mezi teorií ochranného účelu a nexem protiprávnosti (Rechtswidrigkeitsqusammenhang). Správně se však poukazuje na to, že nexus protiprávnosti pomáhá určit odpovědnost za protiprávní jednání, kdežto teorie ochranného účelu normy vyjadřuje rozsah odpovědnosti také př̀ dovoleném chování (viz OETKER, Hartmut. In: KRÜGER, Wolfgang et al. Münchener Kommentar zum Bürgerlichen Gesetzbuch. Band 2: Schuldrecht-Allgemeiner Teil I (』 241-310). 8. vyd. 2019. Dostupné z: Beckonline.de. BGB, \ 249 marg. č. 121; shodně LANGE, Hermann a Gottfried SCHIEMANN. Schadensersatz: Handbuch des Schuldrechts. Band 1. Tübingen: Mohr Siebeck, 2003, s. 102), z důvodu nadbytečnosti tak někteří autoři odmítají kategorii nexu protiprávnosti (srov. cit. lit. in Ibid., pozn. pod čarou č. 141). 
a v. 2 OZ tedy nechrání před pozitivní interesí, nýbrž negativní interesí, kterou obdarovaný utrpí právě proto, že důvěřuje v oprávnění dárce věc převést, resp. v (ne)existenci vlastnosti darované věci. Dárci se totiž vytýká, že obdarovanému „zatajil“ pravý stav věci. ${ }^{19}$ Odmyslíme-li si porušení zmíněné povinnosti (ti. zatajenî), pak se obdarovaný neocitne $\mathrm{v}$ takové majetkové pozici, $\mathrm{v}$ jaké by byl, kdyby dar odpovídal smluvně ujednanému (před takovou újmou ochranný účel in concreto nechránî). Je tedy patrné, že ustanovení \2065 OZ se z hlediska odpovědnosti za nikoliv řádné plnění odchyluje od náhrady pozitivní interese, která je typická pro \2913 OZ, jenž je založen na garanční odpovědnosti. ${ }^{20}$ Vedle negativní interese odpovídá dárce obdarovanému pochopitelně též za interesi integrity (Integritätsinteresse, indemnity interest), ${ }^{21}$ jinými slovy za to, že dárce je povinen nahradit obdarovanému veškeré újmy na jeho právech, právních statcích a zájmech, a to nikoliv jen na těch současných, nýbrž též budoucích. Nejde přitom o škodu spočívající ve vadném plněním (tzv. Mangelschaden), jejíž náhrada by znamenala náhradu pozitivní interese. ${ }^{22}$ Povinnosti, které zde dárce poruší, jsou tzv. sekundární povinnosti, konkrétně ochranné povinnosti, ${ }^{23}$ dovozené $z$ principu poctivosti.

Z hlediska negativní interese obdarovaného mají být nahrazovány majetkové újmy jako kupřr. marně vynaložené náklady na přepravu a převzetí věci, povinnost k náhradě škody z navazujícího obchodu, který obdarovaný nemůže svému smluvnímu partneru splnit, protože se nestal vlastníkem věci atd. Nahraditelné mohou být tzv. následné škody, jež vznikly v důsledku vědomé vady (tzv. Mangelfolgeschaden). Ani při náhradě negativní interese nelze nahrazovat škodu spočívající ve vadném vadě, ${ }^{24}$ byt’ by o ní dárce věděl

19 Shodně i v něm. nauce viz KOCH, Jens. In: WESTERMANN, Harm Peter et al. Münchener Kommentar zum Bürgerlichen Gesetz̧buch. Band 4. Schuldrecht - Besonderer Teil I $\int 433-534$ Finanzierungsleasing CISG. 8. vyd. München: C. H. Beck, 2019. Dostupné z: Beck-online.de. BGB, \ 523 marg. č. 3; GEHRLEIN, Markus. In: HAU, Wolfgang, Roman POSECK et al. Beck'sche Online Kommentar BGB. Stav: 56. Ed. 1. 11. 2020. Dostupné z: Beck-online.de. BGB, $\int 523$ marg. č. 2; MANSEL, Heinz-Peter. In: STÜRNER, Rolf a kol. Jauernig Bürgerliches Geseţ̧buch. 18. vyd. München: C. H. Beck, 2021. Dostupné z: Beck-online.de. BGB. S 523; Z judikatury BGH srov. rozhodnutí BGH ze dne 2. 10. 1981, sp. zn. V ZR 134/80, publik. v Neue Juristische Wochenschrift, 1982, 818, bod 4.

20 Viz KOLMAČKA, Viktor. Přiměřené snížení ceny jako prostředek nápravy narušené subjektivní ekvivalence. Právni roẓbledy, roč. 29, č. 13-14, sub V.1.2.2, s. 462-463.

21 K pojmu srov. MAGNUS, Ulrich. J. von Staudingers Kommentar zum Bürgerlichen Gesetzbuch. Berlin: Sellierde Gruyter, 2013, CISG, Art. 74, marg. č. 20; nebo OTTO, Hansjörg. In: LÖWISCH, Manfred (red.). J. von Staudingers Kommentar zum Bürgerlichen Gesetz̧buch. Buch 2. Recht der Schuldverbältnisse. I 255-304 (Leistungsstörungsrecht 1). 16., upravené vyd. Berlin: Sellier-de Gruyter, 2009, BGB, \ 280, marg. č. E 13.

$22 \mathrm{~K}$ pojmům i s odkazy na literaturu viz KOLMAČKA, Viktor. Přiměřené snížení ceny jako prostředek nápravy narušené subjektivní ekvivalence. Právní rožbledy, roč. 29, č. 13-14, sub V.1, s. 460-463.

$23 \mathrm{~V}$ zahraniční dogmatice se hovoři o tzv. Schutzpflichten, nebo též Rücksichtnahmepflichten (povinnosti ohleduplnosti). Viz OTTO, Hansjörg. In: LÖWISCH, Manfred (red.). J. von Staudingers Kommentar zum Bürgerlichen Gesetzbuch. Buch 2. Recht der Schuldverbältnisse. \ 255-304 (Leistungsstörungsrecht 1). 16., upravené vyd. Berlin: Sellier-de Gruyter, 2009, BGB, \280, marg. č. E 13.

24 Př. jestliže věc má nižší hodnotu v důsledku vědomé vady, nemůže obdarovaný požadovat přes \2913 odst. $1 \mathrm{OZ}$ náhradu této škody. Šlo by totiž o náhradu pozitivní interese. Z charakteru porušené povinnosti ve smyslu \2065 v. $1 \mathrm{OZ}$ jednoznačně plyne, že vědomost vady může vést k náhradě toliko negativní interese či interese integrity. 
(tzv. Mangelschaden). Prostřednictvím náhrady škody nelze saturovat zklamanou důvěru obdarovaného v to, že se jeho jmění rozšírí o částku, kterou měl představovat „bezvadný“ předmět daru (šlo by totiž o náhradu pozitivní interese).

Pro úplnost se dodává, že právo odstoupit od smlouvy dle \ 2065 v. 3 OZ není právem $z$ vadného plnění ve smyslu \1914 an. OZ. Je tomu tak proto, že odstoupení od smlouvy jako prostředek nápravy vadného plnění má význam tehdy, pokud nabyvatel díky jeho výkonu má právo požadovat své plnění zpět, resp. není nucen sám plnit. S tím souvisí též prakticky relevantní aspekt, že výkon dárcova práva odstoupit od smlouvy není vázán na vytýkací lhůtu dle \1921 odst. 1 OZ. ${ }^{25}$ Stěží se proto může uplatnit myšlenka tzv. rychlého průběhu (uskutečněnî) smlouvy, ${ }^{26}$ která se jednak odráží právě v krátké vytýkací lhưtě \1921 OZ, jednak ve specialitě práv z vad oproti jiným právním prostředkům, jejichž právní následky se s právy z vad mohou překrývat.

Na margo se uvádí, že v otázce odpovědnosti za vady nelze rozlišovat mezi darovací smlouvou, kdy je plněno současně při uzavření smlouvy (někdy označováno za tzv. reálné darovánî) a kdy až posléze (tzv. příslib darovánî). ${ }^{27}$ Nutno upozornit, že historicky se vyskytl názor, ${ }^{28}$ jenž prípouštěl odpovědnost dárce za vady ve druhém prŕípadě. Tento prístup byl odůvodňován tím, že soluční smlouva (splněnî) je uzavřena in causa adquirendi, nebot' darující plní výměnou za zánik pohledávky obdarovaného, resp. za osvobození se z dluhu. ${ }^{29}$

25 Viz též EISNER, Berthold. Zur Lehre von der Gewährleistung nach österr. allg. Privatrechte. Grunbüts Zeitschrift, 1912, 39. Band, s. 586.

26 Srov. blíže vč. lit. tam cit. KOLMAČKA, Viktor. Ke vztahu práv z vadného plnění a omylu o vlastnostech předmětu koupě. Právni roẓhledy, 2020, č. 7, s. 229-240, sub V.2.

$27 \mathrm{~K}$ takovému rozlišování viz STANZL, Gustav. In: KLANG, Heinrich, Franz GSCHNITZER et al. Kommentar zum Allgemeinen bürgerlichen Gesetz̧buch: Band 4, HalbBand 1: \ 859-1044. 2. vyd. Wien: Österr. Staatsdruckerei, 1968, s. 586-587.

28 Podaný prŕístup formuloval Minasiewicz v souvislosti s darovací smlouvou, kde se dárce zavazuje dát věc určenou druhově (MINASIEWICZ, Franz. Ueber die Verbindlichkeit des Geschenkgebers bey der Schenkung einer nur der Gattung nach bestimmten Sache, zur Gewährleistung. Zeitschrift für österreichische Rechtsgelehrsamkeit und politische Gesetzkunde, Wien: J. P. Gollinger. Jg., 1837, Band 2, s. 112 a násl.): $\mathrm{Na}$ základě takové darovací smlouvy vzniká dárci pohledávka, přičemž právě ona, s ohledem na širokou koncepci věci, je předmětem darovací smlouvy. Protože splnění dluhu, tj. soluční jednání, vede k zániku dluhu (Verbindlichkeit), jde o úplatné jednání, nebot' platící (plnícî) se placením osvobozuje od svého právního závazku (Ibid., s. 115). Zaplacení dluhu je právním titulem (cit. autor závěr dokládá odkazem na $\int 1461$ ABGB), který dle své přirozenosti vyžaduje novou svobodnou smlouvu (Ibid., s. 117).

29 Mezi reálným darováním a př́slibem darování se rigidně rozlišovalo. Tak např. Dernburg uvádí: „Die Erfüllung des Schenkungsversprechens ist Zablung der aus ihm erwachsenen Schuld, keineswegs selbst Schenkung". (DERNBURG, Heinrich. Pandekten. Band 2: Obligationenrecht. 6. vylepšené vyd. Berlin, 1900, s. 292). Unger: „Das Versprechen selbst enthält die Schenkung, das nachfolgende Geben ist bloß Erfüllung des Verprechens, also Bezablung einer Schuld." (UNGER, Joseph. System des österreichischen allgemeinen Privatrechts. Zweiter Band. 2. nezměněné vyd. Leipzig: Druck und Verlag von Breitkopf \& Härtel, 1863, s. 199, pozn. pod čarou č. 39). Ve stejném duchu i Savigny: „Die Forderung an den Geber als Schenkung ist das, was man das Schenkungsversprechen zu nennen pflegt, und welches viele neuere Schriftsteller als Hauptfall aller Schenkung willkürlich aufgefaßt haben (\ 142). Der Name Schenkungsversprechen könnte leicht zu der Ansicht führen, als wäre das nachfolgende Geben die eigentliche Schenkung, welche nur durch das vorhergehende Geben nothwendig würde. Dieses wäre aber ganz irrig. Das Versprechen ist die wahre und einzige Schenkung, wodurch die Bereicherung schon vollständig bewirkt wird (a), das nachfolgende Geben ist die bloße Bezablung einer Schuld, folglich durchaus keine Schenkung (b)." (SAVIGNY, Friedrich Carl von. System des heutigen römischen Rechts Band 4. Berlin, 1841, s. 118-119). 
Takové argumentaci nelze pochopitelně přitakat. ${ }^{30}$ Osvobození od dluhu není úplatou, a tedy součástí právního titulu nabyté věci, nýbrž důsledkem soluce. ${ }^{31}$ Causa solvendi není subtypem causae adquirendi. Lze proto uzavřít, že práva z vad (\1914 a násl. OZ) nenajdou uplatnění nejen v prŕpadě \2055 odst. 1 alt. 2 OZ (tzv. reálné darovánî), ale ani v případě $\int 2055$ odst. 1 alt. $1 \mathrm{OZ}$ (tzv. příslib daru).

\section{2 Částečně bez(úplatná) smlouva}

O tom, zda je určitá smlouva částečně bezúplatnou, rozhoduje ryze vưle stran, a proto taková smlouva musí vykazovat duplicitní kauzu: ${ }^{32}$ základem smlouvy musí být jak causa adquirendi, tak causa donandi. ${ }^{33,34}$ Jinými slovy, vưlí stran je, aby poskytnutí předmětu

30 Že neexistuje věcný důvod rozlišovat mezi tím, zda jde o darování species, nebo věci určené druhem, stejně jako zda jde o darovací smlouvu ve smyslu \ 2055 odst. 1 alt. 1, event. alt. 2 OZ, uváděl již Hasenöhrl (Viz HASENÖHRL, Victor. Das osterreichische Obligationenrecht: in systematischer Darstellung mit Einschluss der handels- und wechselrechtlichen Lebren. II Band. Wien: Manz'sche K. K. Hof-Verlags- und Universitätsbuchhandlung, 1890, s. 443-445).

31 Příznačně WINIWARTER, Joseph von. Das österreichische bürgerliche Recht. IV. Theil. 2. rozšířené a vylepšené vyd. Wien: Braumüller und Seidel, 1844, s. 86, pozn. pod čarou č. 1. Přiléhavě Eisner uvádí, že na splnění závazku z prríslibu darování nemůže být nahlíženo jako na úplatné právní jednání, nebot' zrušení závazku není protiplnění př́jemce, tj. úplatou za plnění, nýbrž přímým důsledkem plnění. Vedle toho může být splnění pohledávky chápáno jako samostatné právní jednání odlišné svojí kvalitou a účinky, pokud jde o datio in solutum (EISNER, Berthold. Zur Lehre von der Gewährleistung nach österr. allg. Privatrechte. Grunbüts Zeitschrift, 1912, 39. Band, s. 587.).

32 Weirauch hovoří o dvojím účelu v právním styku (Verkebrszweck). Viz WEIRAUCH. Die gemischte Shenkung. In: GRUCHOT, J. A. Beiträge zur Erläuterung des deutschen Rechts. Hamm: Grote, Band 48, 1904, s. 231-232.

33 Srov. MÜLLER, Wilhelm. Die gemischte Schenkung. Jherings Jabrbücher für die Dogmatik des bürgerlichen Rechts. Band 48. Jena: Fischer, 1904, s. 210; k obojí kauze srov. z rak. nauky BOLLENBERGER, Raimund. In: KOZIOL, Helmut, Peter BYDLINSKI, Raimund BOLLENBERGER et al. Kurzkommentar zum $A B G B$. 3. vyd. Wien: Springer, 2010, $\int 940$, marg. č. 8; nebo ERTL, Gunter. In: FENYVES, Attila, Ferdinand KERSCHNER, Andreas VONKILCH et al. Großkommentar zum ABGB - Klang Kommentar. $\int 938$ bis 1001. 3. vyd. Wien: Verl. Österreich, 2013, \938, marg. č. 38.

34 Srov. HASENÖHRL, Victor. Das osterreichische Obligationenrecht: in systematischer Darstellung mit Einschluss der handels- und wechselrechtlichen Lehren. I Band. Wien: Wilhelm Braumüller, 1881, s. 325. Z prvorepublikové judikatury viz rozhodnutí Nejvyššího soudu Československé republiky ze dne 8. 1. 1932, sp. zn. Rv II 791/30, publik. ve Vážného sbírce pod č. 11329, nebo rozhodnutí ze dne 7. 11. 1922, sp. zn. Rv II 189/22, publik. ve Vážného sbírce pod č. 1982. Z aktuální české literatury ELIÁŠ, Karel. In:

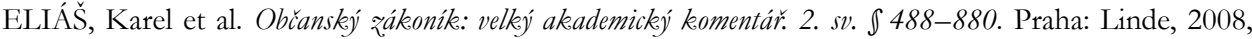
s. 1877; BRUNCKO, Stanislav. Odvolání daru pro nouzi a vyživovací povinnost obdarovaného. Právní roz̧ledy, 2014, č. 19, s. 656-659, sub III; nebo ELISCHER, David. Darováni a jeho podoby v novém soukromém právu. Praha: Wolters Kluwer, 2016, s. 37. 
plnění nastalo částečně za úplatu (ekvivalentně), částečně bez úplaty (neekvivalentně). Přiléhavě se v judikatuře BGH (něm. Spolkový soudní dvůr) ${ }^{35}$ uvádí: ${ }^{36}$

„Smišené darováni je zde tehdy, pokud obdarovaný je obohacen prebytkem hodnoty majetkové výhody (Zuwendung) srovnané s jeho protiplnèním, pričemžs strany jsou si tohoto prebytku védomy a subjektivně dohodnuty, že prebývajici část majetkové výhody má být obdarovanému bezúplatně poskytnuta. Předpokladem však neni, že objektivni hodnota majetkové výhody čini prinejmenšm dvojnásobek protiplnèni."

Za modelový prríklad vyznačující se podanými znaky lze označit smíšené darovaní (negotium cum donatione mixtum). Pojmem „smíšené darováni“" se označuje nejen prostá kombinace darování a koupě, ale i darovaní s ostatními úplatnými zákonnými smluvními typy (směnou, nájmem, zápůjčkou atd.). ${ }^{37} \mathrm{~V}$ naposledy uvedeném významu je užíván i v předkládaném př́spěvku.

Fenoménu částečně (bez)úplatných smluv si byl vědom i zákonodárce, nebot' jej po vzoru \935 alt. 4 ABGB vyloučil z ochrany poskytované institutem laesio enormis (srov. \1794 odst. $1 \mathrm{OZ}$ ).

Značná disproporce plnění a protiplnění není předpokladem smíšeného darování, nýbrž toliko jeho indicií. ${ }^{38} \mathrm{Z}$ hlediska prosaditelnosti nároku na plnění či jiného práva rezultujícího ze závazkově právního poměru (např. právo odvolat dar, odstoupit od smlouvy, nárokovat přiměřené snížení ceny etc.) nelze zapomínat, že právě věřitel je povinen tvrdit a prokázat kauzu závazku (〔 1791 odst. 1 věta za středníkem OZ). Z indicie nepoměru

35 Podobně i OGH (rak. Nejvyšší soudní dvưr) v rozhodnutí ze dne 14. 1. 2010, sp. zn. 6 Ob 232/09z, s odkazy na judikaturu, jmenovitě RIS-Justiz RS0019356, RS0019293, uvádí: „Eine gemischte Schenkung setzt nach ständiger Rechtsprechung einerseits ein objektives Missverhältnis żischen Leistung und Gegenleistung, andererseits Schenkungsabsicht voraus. " [Smíšené darování předpokládá dle ustálené rozhodovací praxe na jedné straně objektivní nepoměr mezi plněním a protiplněním, na druhé straně úmysl darovat]. Dostupné z: http://ris.bka.gvat; Obdobně i GEHRLEIN, Markus. In: HAU, Wolfgang, Roman POSECK et al. Beck'sche Online Kommentar BGB. Stav: 56. Ed. 1. 11. 2020. Dostupné z: Beck-online.de. BGB, \516, marg. č. 13. Tomu však lze namítnout, že strany si mohou věc subjektivně cenit na nižší hodnotu než objektivní; rozhodující je totiž subjektivní ekvivalence (sub 1.1).

36 Viz rozhodnutí BGH ze dne 18. 10. 2011, sp. zn. X ZR 45/10: „Eine gemischte Schenkung liegt vor, wenn der Beschenkte durch einen Überschuss des Werts der Zuwendungen verglichen mit seinen Gegenleistungen objektiv bereichert wird, die Vertragsparteien sich dieses Überschusses bewusst und subjektiv darüber einig sind, jedenfalls den überschieBenden Zuwendungsteil dem Beschenkten unentgeltlich zuzuwenden. Dies setzt nicht voraus, dass der objektive Wert der Zuwendung mindestens das Doppelte der Gegenleistungen beträgt."

37 Srov. MÜLLER, Wilhelm. Die gemischte Schenkung. Jherings Jabrbücher für die Dogmatik des bürgerlichen Rechts. Band 48. Jena: Fischer, 1904, s. 211; shodně GOLDSCHMIDT, Siegfried. Die gemischte Schenkung nach Reichsrecht. Berlin: Verlag von Struppe \& Winckler, 1907, s. 1; shodně s odkazy na obecnoprávní nauku i WEIRAUCH. Die gemischte Shenkung. In: GRUCHOT, J. A. Beiträge zur Erläuterung des deutschen Rechts. Hamm: Grote, Band 48, 1904, s. 230. Z rakouské nauky takto STANZL, Gustav. In: KLANG, Heinrich, Franz GSCHNITZER et al. Kommentar zum Allgemeinen bürgerlichen Gesetzbuch: Band 4, HalbBand 1: $\int 859-1044$. 2. vyd. Wien: Österr. Staatsdruckerei, 1968, s. 590, sub C. I.

38 Shodně s odkazy na rakouskou judikaturu i JANOUŠEK, Michal. In: PETROV, Jan et al. Občanský zákoník: komentár. Praha: C. H. Beck, 2017, \2055, marg. č. 16. 
plnění a dodatečných okolností (např. blízký vztah, událost odůvodňující vděčnost) lze však na vưli o dvojí kauze usuzovat. ${ }^{39}$ Správný je závěr, že nápadný nepoměr vzájemných plnění s ohledem na obecnou zkušenost sám o sobě zakládá tzv. zkušenostní domněnku (tatsächliche Vermutung), ${ }^{40}$ že je dána vưle obdarovat. ${ }^{41}$ Protistraně však nadále zůstává možnost domněnku protidůkazem rozptýlit.

Představený př́stup v rozlišování mezi úplatností a bezúplatností nelze bez dalšího stavět naroveň se situacemi, kdy je (bez)úplatnost kritériem dobrověrného nabytî (\984 OZ) ${ }^{42}$ nebo relativní neúčinnosti (\591 OZ, \240 InsZ), ${ }^{43}$ nebot' zde nemůže být úplatnost posuzována ryze dle vůle smluvních stran, tedy výlučně subjektivní ekvivalencí. Je tomu tak proto, že při interpretaci tohoto znaku skutkových podstat citovaných norem jsou v kolizi i zájmy třetích subjektů (dotčeného vlastníka a zkráceného věřitele), nikoliv jen těch, z jejichž vưle se určuje (ne)ekvivalentní povaha závazku. Nikoliv zřejmá je též otázka, zda nabytí od neoprávněného či relativní neúčinnost se vyznačují právním následkem „všechno nebo nic“, což z hlediska účelnosti se může jevit jako uspokojivější závěr, nebo lze akceptovat parcelaci převáděného oprávnění k věci (typicky vlastnického práva nebo oprávnění z pohledávky), a tedy připustit dle poměru (bez)úplatnosti i založení spoluvlastnictví (nabytí od neoprávněného), resp. rovnou peněžního ekvivalentu,

39 Srov. ERTL, Gunter. In: FENYVES, Attila, Ferdinand KERSCHNER, Andreas VONKILCH et al. Großkommentar zum ABGB - Klang Kommentar. \938 bis 1001. 3. vyd. Wien: Verl. Österreich, 2013, \938, marg. č. 38.

40 Česká terminologie je při užívání tohoto pojmu značně rozkolísaná. V literatuře se tak můžeme setkat s různými označeními: skutková domněnka (např. LAVICKÝ, Petr. Dỉkazní brémeno v civilním ríżení soudnim. Praha: Leges, 2017, s. 229; nebo TICHÝ, Luboš a Jan BALARIN. Míra důkazu a důkazní břemeno. In: ZOUFALÝ, Vladimír. (ed.). XXVI. Karlovarské právnické dny. Praha: Leges, 2018, s. 176 a násl.), faktická, popř. praktická domněnka (viz MELZER, Filip a Kristián CSACH. In: MELZER, Filip, Petr TÉGL et al. Občanský zákonik: velký komentár. Svazek IX. 』 2894-3081. Praha: Leges, 2018, s. 1447, \2997, marg. č. 78, 79). K částečnému vymezení a odlišení od vyvratitelné domněnky, důkazu prima facie a důkazu indicí jakož i k dalším odkazům na literaturu srov. KOLMAČKA, Viktor. Procesní a materiální úcinky obchodního potvrzovacího dopisu. Diplomová práce. Brno: Masarykova univerzita, Právnická fakulta, 2019, s. 27 a násl., vč. poznámky pod čarou č. 61. Vedoucí práce Josef Kotásek. Dostupné z: https:// is.muni.cz/th/vqwfj/ [cit. 13. 2. 2021].

41 Takto např. judikatura BGH, jmenovitě rozhodnutí ze dne 22. 10. 2019, sp. zn. X ZR 48/17, publik. v Neue Juristische Wochenschrift Rechtsprechungs-Report Zivilrecht, 2020, 179, marg. č. 12 (souhlasně i nauka, viz s dalšími odkazy GEHRLEIN, Markus. In: HAU, Wolfgang, Roman POSECK et al. Beck'sche Online Kommentar BGB. Stav: 56. Ed. 1. 11. 2020. Dostupné z: Beck-online.de. BGB, \516, marg. č. 13).

42 Viz např. TÉGL, Petr. Úplatnost nabytí věcného práva jako podmínka fungování materiální publicity veřejných seznamů v novém občanském zákoníku. Právní roz̧bledy, 2013, č. 1, s. 28-33, sub IV, V.

43 Kupř́kladu Pulkrábek navrhuje posuzovat úplatnost objektivní ekvivalencí. Tímto prizmatem by tak smíšená darování spadala výlučně pod $\ 591$ OZ (viz PULKRÁBEK, Zdeněk. In: MELZER, Filip, Petr TÉGL et al. Občanský zákoník: velký komentár. Svazeke III, \419-654 a souvisejici společná a prèchodná ustanoveni. Praha: Leges, 2014, \590-591, marg. č. 38.). 
jenž odpovídá nároku na jeho vypořádání. ${ }^{44}$ Váženy totiž musí být zájmy všech dotčených subjektů, včetně stojících vně dané právní dispozice.

Protože pro úvahy o kauze hraje rozhodující roli subjektivní ekvivalence stran, může smíšené darování dokonce představovat i situace, kdy dle měřítek objektivní ekvivalence obdrží hodnotnější plnění strana, která je současně dárcem. Třebaže budou takové případy raritní, per se vyloučeny nejsou (srov. však výše cit. judikaturu OGH).

Nutno podotknout, že situace, kdy je věc pouze prodávána, ač př́liš levně, nebo simulovaně kupována, ale disimulovaně darována, nejsou předmětem zdejšího zájmu. Nemají totiž nic společného s výše podaným vymezením smíšeného darování. Věnována tak není ani pozornost výhodným koupím, či nevýhodným prodejům, kde causa donandi absentuje.

Od smíšeného darování je třeba dále odlišit darování s př́ikazem (donatio sub modo), které se rovněž vyznačuje určitým vztahem ,vzájemnosti“, a to na jedné straně poskytnutím daru a na druhé provedením př́kazu (nikoliv ale ve významu synallagma). ${ }^{45}$ Poskytnutí daru není v případě darování s příkazem částečným protiplněním za provedení prŕkazu. ${ }^{46}$ Pro smíšené darování a darování s příkazem je přitom příznačné, že obdarovaný musí darováním získat materiální, nebo příp. alespoň imateriální výhodu. Bez aspektu, byt' imateriální, výhody není totiž myslitelná causa donandi ${ }^{47}$

Jak má být darování s příkazem vymezeno vưči smíšenému darování, je silně sporné. Dělící kritérium představuje dle části nauky ${ }^{48}$ a německé judikatury ${ }^{49}$ to, zda má obdarovaný financovat provedení př́kazu z daru (darování s př́íkazem), anebo nezávisle na něm (smíšené darovánî). Plnění příkazu je přitom částečným protiplněním. Tento názor se jeví být

$44 \mathrm{~K}$ částečné odporovatelnosti (relativní neúčinnosti) v části, která je poskytnuta bezúplatně, se hlásí např. KAYSER, Godehard a Nils FREUDENBERG. In: STÜRNER, Rolf a kol. Münchener Kommentar zur Insolvenzordnung. Band 2. \80-216 InsO. 4. vyd. München: C. H. Beck, 2019. Dostupné z: Beck-online.de. InsO, \134, marg. č. 42. Německé právo v \134 odst. 1 insolvenčního řádu umožňuje insolvenčním věritelům dovolávat se relativní neúčinnosti (Anfechtung) plnění, které bylo poskytnuto insolvenčním dlužníkem bezúplatně.

45 U tzv. reálného darování vzniká jednostranně zavazující smlouva, kdežto u darovací smlouvy, v níž se dárce zavazuje převést vlastnické právo k věci na obdarovaného, jde o dvoustranně zavazující smlouvu. Povinnost splnit př́kaz však není úplatou za převod daru (srov. s podrobnostmi CHIUSI, Tiziana J. In: MARTINEK, Michael (red.). J. von Staudingers Kommentar zum Bürgerlichen Gesetzbuch. Buch 2, Recht der Schuldverbältnisse. \516-534 (Schenkungsrecht). Berlin: Sellier-de Gruyter, 2013, 』 525, marg. č. 15).

46 Viz i JANOUŠEK, Michal. In: PETROV, Jan et al. Občanský zákoník: komentár. Praha: C. H. Beck, 2017, \2055, marg. č. 17.

47 Srov. KOCH, Jens. In: WESTERMANN, Harm Peter et al. Münchener Kommentar zum Bürgerlichen Gesetzbuch. Band 4. Schuldrecht-Besonderer Teil I 433-534 Finanzierungsleasing CISG. 8. vyd. München: C. H. Beck, 2019. Dostupné z: Beck-online.de. BGB, \ 525, marg. č. 5, 6.

48 Ibid., \525, marg. č. 7; GEHRLEIN, Markus. In: HAU, Wolfgang, Roman POSECK et al. Beck'sche Online Kommentar BGB. Stav: 56. Ed. 1. 11. 2020. Dostupné z: Beck-online.de. BGB, \ 525, marg. č. 7.

49 Rozhodnutí BGH ze dne 7. 4. 1989, sp. zn. V ZR 252/87 (Hamm), publik. v Neue Juristische Wochenschrift, roč. 1989, s. 21-22. 
následováníhodný i v českém právu, nebot’ financování splnění příkazu z předmětu daru plyne implicite z ratia povinnosti dárce plnit napřed (srov. \2064 odst. 1 OZ). Vedle toho je též správný závěr, že plnění příkazu je částečně ekvivalentem za dárcovo plnění, které slouží dvojí kauze: provedení prríkazu a obdarování př́ikazníka.

Smíšené darování se nedotýká jen otázky možných práv z vadného plnění a jejich rozsahu (\ 1914 an. OZ), ale v prvé řadě požadavku formy (\$ 2057 odst. 2 OZ), dále i možnosti odvolání daru pro nouzi (\$ 2068 an. OZ), př́p. pro nevděk (\ 2072 an. OZ). Těmto otázkám zde však není věnována pozornost. ${ }^{50}$ Problém dvojí kauzy se pochopitelně promítá i do zvlášt’ upravené odpovědnosti cedenta vůči cesionáři za vady cedované pohledávky ( $(1885$ OZ), což zde není rovněž rozebíráno.

\section{Právní povaha smíšeného darování}

\section{1 Úvod}

Z př́padů smíšených smluv se zpravidla vyčleňují situace, kdy ve dvojí roli poskytovatele úplatného a bezúplatného plnění (dále cum grano salis též jen „dárce“) vystupuje současně kupující, příp. strana jiného úplatného zákonného smluvního typu. Tak je tomu kuprr. tam, kde věc v hodnotě 100 je koupena za 300, přičemž subjektivní ekvivalence odpovídá objektivní. Jako elegantní řešení se nabízí přistupovat k dané situaci jako k tzv. jednoduché mnohosti smluv, tedy rozčlenit závazek na kupní smlouvu (věc oproti 100) a darovací smlouvu (200 jako dar). Je třeba si uvědomit, že zmíněné části plnění se vztahují k různým účelům (100 jako úplata, 200 jako dar) ${ }^{51}$ a současně že jejich pojítkem je toliko společný kontext plnění. Z toho důvodu řada autorů pojednávajících o smíšeném darování tuto typovou skupinu případů vylučuje ze smíšeného darování:

„smišsené darováni může být dáno jen tehdy, když uzavrenim smlouvy jsou zakládány právní pomèry, které ve svém celku musí být uchopovány jako jediný závazek.."

Komplikovanost právního uchopení smíšeného darování vyplývá na povrch proto až tam, kde věc v hodnotě 300 je koupena za 100, nebot' tehdy je třeba se na právní poměr dívat jako na celek. Hovořit o dvou smlouvách, jejichž předmětem je převod spoluvlastnických podílů, by bylo vrcholem právně juristické fikce a jedné z teorií, která upadla v zapomnění. Jestliže tedy na věci lpí vada, která snižuje její hodnotu na 150, pak se nabízí otázka, zda může vůbec kupující (obdarovaný) uplatnit právo odstoupit od smlouvy, nebo požadovat přiměřené snížení ceny či odstranění vady. Za předpokladu, že kupující smí odstoupit od smlouvy, jakým způsobem má nastat vypořádání?

\footnotetext{
50 Srov. však dále v textu citovanou literaturu, kde se tyto aspekty zkoumají.

51 GOLDSCHMIDT, Siegfried. Diegemischte Schenkung nach Reichsrecht. Berlin: Verlag von Struppe \& Winckler, 1907, s. 36-37.

52 Takto Ibid., s. 42.
} 
Má si nabyvatel věc ponechat, nebo naopak ji zciziteli vrátit a ten mu má vyplatit v penězích hodnotu daru, nebo má vzniknout spoluvlastnictví k věci?

Šíri a způsobu aplikovatelnosti jednotlivých pravidel úplatného zákonného smluvního typu (modelově kupní smlouvě \2079 an. OZ) a darovací smlouvy (\2055 an. OZ) na prrípady smíšených smluv se věnovala celá ràa teorií. Pro pochopení problematiky smíšeného darování jsou tyto koncepce nejprve představeny a posléze je věnována pozornost tomu, jakým zpo̊sobem mají být práva z vad realizovaná.

Jako základní teorie, jak právně zacházet se smíšeným darováním, se uvádí: ${ }^{53,54}$

a) teorie oddělení (Trennungstheorie),

b) teorie jednoty (Einheistheorie),

c) teorie o smlouvě sui generis (contractus sui generis),

d) teorie o hodnocení účelu (Zweckwürdigungstheorie).

Nadto se objevila i tzv. nauka o darování uzavření (Abschlussschenkung), podle které není darem samotná věc, nýbrž právě uzavření smlouvy za nižší, příp. vyšší cenu. ${ }^{55} \mathrm{Jde}$ tedy o dvě bezprostředně na sebe navazující smlouvy, kdy uzavřením kupní smlouvy nastává soluce darovací smlouvy. ${ }^{56}$ Teorie však pro svoji juristickou umělost a fikci dvou navazujících smluv právem nedoznala sluchu.

Každá ze jmenovaných teorií vede u výše položených sporných otázek bud’ k žádným, či částečně odlišným řešením.

53 Srov. SCHLINKER, Steffen. Sachmängelhaftung bei gemischter Schenkung: - Aktuelle Fragen nach der Reform des Schuldrechts. Archiv für die civilistische Praxis, Tübingen: Mohr Siebeck, 2006, 206. Band, H. 1 (2006), s. 34-38.

54 Např. Ertlzmiňuje jen teorii oddělení a teorii jednoty (Viz ERTL, Gunter. In: FENYVES, Attila, Ferdinand KERSCHNER, Andreas VONKILCH et al. Großkommentar zum ABGB - Klang Kommentar. $\int 938$ bis 1001. 3. vyd. Wien: Verl. Österreich, 2013, 』 938, marg. č. 41). Shodně i STANZL, Gustav. In: KLANG, Heinrich, Franz GSCHNITZER et al. Kommentar zum Allgemeinen bürgerlichen Gesetz̧buch: Band 4,

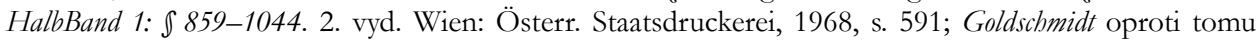
hovoří o: a) dvojí smlouvě (Doppelvertrag), čímž má na mysli teorii oddělení, b) mnohosti smluv a c) jednotné smlouvě, čímž míní teorii jednoty (Viz GOLDSCHMIDT, Siegfried. Die gemischte Schenkung nach Reichsrecht. Berlin: Verlag von Struppe \& Winckler, 1907, s. 16 a násl.).

55 Takto Enneccerus. Lehrbuch des Bürgerlichen Rechts $I^{3} \int 347$, cit. dle CHIUSI, Tiziana J. In: MARTINEK, Michael (red.). J. von Staudingers Kommentar zum Bürgerlichen Gesetzbuch. Buch 2, Recht der Schuldverhältnisse. \516-534 (Schenkungsrecht). Berlin: Sellier-de Gruyter, 2013, \ 516, marg. č. 77.

56 Viz CHIUSI, Tiziana J. In: MARTINEK, Michael (red.). J. von Staudingers Kommentar zum Bürgerlichen

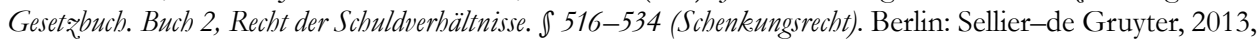
\516, marg. č. 77. 


\subsection{Teorie oddělení}

Teorie oddělení se vyznačuje rozložením smlouvy na dvě části (tj. kupní a darovací smlouvu), a to se záměrem, aby se každá z nich podřídila pod ten který okruh pravidel zákonného smluvního typu. ${ }^{57,58}$ Nepanovala však jednota na tom, jak má být dělení provedeno.

Lammfromm ${ }^{59}$ zastával názor, že ustanoveními o darování se má řídit ta část, která představuje slevu z původně stanovené kupní ceny. Uváděl, že u závazků koncipovaných na podkladě causa adquirendi sleduje každá ze stran obohacení svého majetku. Oproti tomu u causea donandi hodlá jedna ze stran obohatit jen majetek protistrany. Plnění na obě kauzy je tak ze své podstaty vyloučeno, nebot' dá přeci rozum, že plnění věci (Sachleistung) nemůže sloužit současně obohacení vlastního a cizího majetku. Smíšené darování je však dle něj myslitelné při snížení předem stanovené ceny. ${ }^{60}$ Podobně i Dernburg ${ }^{61}$ uvádí: Co chce prodávající darovat, je část kupní ceny, kterou by mohl nárokovat jako hodnotu předmětu koupě.

Z těchto tezí se pak podává, že předmětem darování je peněžní obnos, který se reálně nebo fiktivně získá oceněním předmětu plnění na základě adekvátní nebo obvyklé ceny. ${ }^{62}$

Nesprávnost prezentovaného názoru ${ }^{63}$ dokládá, že pozdější snížení ceny není ničím jiným než fází kontraktace. Skutečnou ofertou je právě až nabídka kombinující úplatnost s bezúplatností. ${ }^{64}$ Přiléhavý je i postřeh, že původně vyšší stanovená cena se nikdy neocitla $\mathrm{v}$ majetku zcizitele (dárce), a proto nelze tvrdit, že právě o ni byl majetek

57 Srov. MÜLLER, Wilhelm. Die gemischte Schenkung. Jherings Jabrbücher für die Dogmatik des bürgerlichen Rechts. Band 48. Jena: Fischer, 1904, s. 211; EHRENZWEIG, Armin a Josef KRAINZ. Der allgemeine Teil und das Sachenrecht. 5., zcela přepracované vyd. Wien: Manzsche k. u. k. Hof-Verlags- und UniversitätsBuchhandlung, 1913, s. 327; KOCH, Jens. In: WESTERMANN, Harm Peter et al. Münchener Kommentar zum Bürgerlichen Gesetz̧buch. Band 4. Schuldrecht - Besonderer Teil I \433-534 Finanzierungsleasing CISG. 8. vyd. München: C. H. Beck, 2019. Dostupné z: Beck-online.de. BGB, \516, marg. č. 37.

58 Zastáncem této starší teorie byl kupř. Unger (Viz UNGER, Joseph. System des österreichischen allgemeinen Privatrechts. II. Band. 2. nezměněné vyd. Leipzig: Breitkopf und Härtel, 1863, s. 220).

59 Viz LAMMFromm, H. Teilung, Darlehen, Auflage und Umsatzvertrag. 1897, s. 134 a násl. Cit. dle MÜLLER, Wilhelm. Die gemischte Schenkung. In: Jherings Jabrbücher für die Dogmatik des bürgerlichen Rechts. Band 48. Jena: Fischer, 1904, s. 212, pozn. pod čarou č. 3; Lammfrommovy teze jsou rozebrány též in GOLDSCHMIDT, Siegfried. Die gemischte Schenkung nach Reichsrecht. Berlin: Verlag von Struppe \& Winckler, 1907, s. 18 a násl.

60 Ibid.

61 Viz DERNBURG, Heinrich. Die Schuldverbältnisse nach dem Rechte des Deutschen Reichs und Preußens. Band 2: Einzelne Obligationen. 4. vyd. Halle a. d. S., 1915, s. 177-178.

62 Srov. SCHLINKER, Steffen. Sachmängelhaftung bei gemischter Schenkung: - Aktuelle Fragen nach der Reform des Schuldrechts. Archiv für die civilistische Praxis. Tübingen: Mohr Siebeck, 2006, 206. Band, H. 1 (2006), s. 34

63 K zevrubné protiargumentaci viz GOLDSCHMIDT, Siegfried. Die gemiscbte Schenkung nach Reicbsrecht. Berlin: Verlag von Struppe \& Winckler, 1907, s. 19 a násl.

64 Viz MÜLLER, Wilhelm. Die gemischte Schenkung. Jherings Jahrbücher für die Dogmatike des bürgerlichen Rechts. Band 48. Jena: Fischer, 1904, s. 214. 
nabyvatele bezúplatně navýšen. ${ }^{65}$ Ostatně kdyby byl zcizitel (dárce) z pohledávky oprávněn a v určité části ji prominul, pak jde o dvě smlouvy (nejprve koupi, poté darovánî); takový postup je v jednom korespondujícím projevu vưlí obou stran nemyslitelný. ${ }^{66}$ Další potíž tkví v tom, že aby zmíněný prístup autorů prakticky mohl fungovat, musela by být nejprve stanovená kupní cena (tj. výchozí částka, z níž se snižuje na skutečnou částečnou úplatu) ztotožněna s odpovídající obvyklou cenou věci; jinak by nebylo možné odlišit smíšené darování od kupní smlouvy, na niž posléze navazuje částečné prominutí dluhu. ${ }^{67}$ Vedle toho se vyskytoval prístup, který naopak stavěl na hodnotě věci. ${ }^{68}$ Darována (causa donandi) je ta část věci, jejíž hodnota není kryta penězi, vice versa koupena (causa adquirendi) zase ta část, jejíž hodnota kryta je. ${ }^{69}$ Poskytnutá věc je tak sama posuzována jako prostředek pro oba účely smlouvy. Nebylo-li zřejmé, v jaké části je předmět darován, přihlíželo se k objektivní hodnotě věci, nebot' z ní strany údajně konkludentně vycházely. ${ }^{70} \mathrm{Na}$ konkludentní charakter bylo možné uzavríit díky domněnce, jež měla pramenit z obecné zkušenosti. ${ }^{71}$ Dle popisovaného př́istupu je tak věc rozdělena na ideální podíly, přičemž jeden se řídí ustanoveními o koupi (př́p. jiného úplatného zákonného smluvního typu), druhý pak ustanoveními o darování. ${ }^{72}$ Smíšené darování má tak charakter dvojí smlouvy (Doppelvertrag). ${ }^{73}$

65 Viz WEIRAUCH. Die gemischte Shenkung. In: GRUCHOT, J. A. Beiträge zur Erläuterung des deutschen Rechts. Hamm: Grote, Band 48, 1904, s. 242-243.

66 Srov. výtku k výše citovanému názoru Enneccera.

67 V takovém prípadě ale na právní poměr dopadají veškerá pravidla o kupní smlouvě. Se smíšeným darováním je tak tato situace dvou postupně uzavřených smluv (nejprve kupní smlouva a posléze darovací smlouva, jejíž dispozici představuje prominutí dluhu, tj. částečné kupní ceny) prima facie odlišná.

68 Takto napr. NIPPEL, Franz Xaver. Erläuterung des allgemeinen bürgerlichen Gesetz̧buches für die gesamten deutschen Länder der österreichisschen Monarchie, mit besonderer Berücksichtigung des pract. Bedürfnisses. VI Band. $\int 859$ bis einschließig 982. Grätz: Damian und Sorge, 1833, s. 212; Srov. Goldschmidtem citovaný přehled takových autorů GOLDSCHMIDT, Siegfried. Die gemischte Schenkung nach Reichsrecht. Berlin: Verlag von Struppe \& Winckler, 1907, s. 25, poznámka pod čarou č. 30.

69 Takto kupř. SAVIGNY, Friedrich Carl von. System des beutigen Römischen Rechts. Band 4. Berlin, 1841, s. 103; viz další odkazy na lit. obecnoprávní nauky a německou literaturu MÜLLER, Wilhelm. Die gemischte Schenkung. Jherings Jabrbücher für die Dogmatik des bürgerlichen Rechts. Band 48. Jena: Fischer, 1904, s. 215-216, vč. poznámky pod čarou č. 9; srov. i GOLDSCHMIDT, Siegfried. Die gemischte Schenkung nach Reichsrecht. Berlin: Verlag von Struppe \& Winckler, 1907, s. 25-26.

70 KÖPPEN, W. Das negotium mixtum cum donatione nach Pandektenrecht und Reichsgesetzen. Druck von W. Pilz, 1901, s. 28. Cit. dle MÜLLER, Wilhelm. Die gemischte Schenkung. Jherings Jabrbücher für die Dogmatike des bürgerlichen Rechts. Band 48. Jena: Fischer, 1904, s. 217; shodně GOLDSCHMIDT, Siegfried. Die gemischte Schenkung nach Reichsrecht. Berlin: Verlag von Struppe \& Winckler, 1907, s. 26.

71 Viz GOLDSCHMIDT, Siegfried. Die gemischte Schenkung nach Reichsrecht. Berlin: Verlag von Struppe \& Winckler, 1907, s. 26-27.

72 Takto WEIRAUCH. Die gemischte Shenkung. In: GRUCHOT, J. A. Beiträge zur Erläuterung des deutschen Rechts. Hamm: Grote, Band 48, 1904, s. 217; podobně i judikatura Reichsgerichtu (RGZ 163, 236 an.), k tomu srov. další odkazy podané in CHIUSI, Tiziana J. In: MARTINEK, Michael (red.). J. von Staudingers Kommentar zum Bürgerlichen Gesetzbuch. Buch 2, Recht der Schuldverhältnisse. I516-534 (Schenkungsrecht). Berlin: Sellier-de Gruyter, 2013, \516, marg. č. 75.

73 Viz GOLDSCHMIDT, Siegfried. Die gemischte Schenkung nach Reichsrecht. Berlin: Verlag von Struppe \& Winckler, 1907, s. 27. 
I tento přistup je hoden kritiky. Je třeba pritakat námitce, že rozdělení ideálních podílů $z$ hlediska uplatnitelnosti práv z vad je nemyslitelné. ${ }^{74}$ Faktické vady totiž nelpí na podílech, nýbrž na substanci věci. Jestliže na věci lpí vada, dle čeho učiníme závěr, že se týká podílu, jenž byl darován (tj. darovací smlouvy), či naopak podílu, jenž byl úplatně převeden (tj. kupní smlouvy)?

Naproti tomu zde zastávaný názor považuje za pochybnou námitku, že by nedodržením formy právního jednání vzniklo spoluvlastnictví a obtíže spojené s jeho vypořádáním, nebot' nabyvatel by se stal vlastníkem věci jen v té části, v jaké byla koupena. ${ }^{75}$ Zmíněná výtka neobstojí, protože jednu „smlouvu“ pro její závislost na druhé nelze takto formálně oddělit. Jak kupní, tak darovací smlouva jsou uzavřeny právě proto, že byla uzavřena každá z nich. Ač teorie obě části uměle rozděluje, pak jí dle zde zastávaného názoru nelze podsouvat i to, že současně popírá jejich vzájemně závislý charakter. Jen výjimečně by bylo lze z okolností uzavření smlouvy dospět k závěru, že zcizitel by byl býval ochoten věc darovat zcela bezúplatně, nebo nabyvatel ji nabýt za plnou hodnotu odpovídající subjektivní ekvivalenci.

\subsection{Teorie jednoty}

Ideji závazkového vztahu neodporuje, že jednotlivé nároky z něj rezultující získávají samostatnou existenci a význam. Jednotné zacházení je pak možné tehdy, pokud uzavřením smlouvy jsou založeny takové právní vztahy, jež ve své celistvosti vyžadují, aby byly uchopovány jako jediný závazkový poměr. ${ }^{76}$

Teorie jednoty reagující na nedostatky teorie oddělení staví na tom, že smíšený právní poměr nemusí být za účelem právního posouzení rozložen do dvou částí, nýbrž má být chápán jako celek. Pro teorii jednoty je však př́iznačné binární uvažování: smlouva má být in toto chápána bud’ jako koupě, či jako darování. ${ }^{77}$ Sporné však bylo, co má být výchozím kritériem pro určení zákonného smluvního typu. ${ }^{78}$

74 Přiléhavě GOLDSCHMIDT, Siegfried. Die gemischte Schenkung nach Reichsrecht. Berlin: Verlag von Struppe \& Winckler, 1907, s. 28: „Ein Mangel an dem ideelen Bruchteil einer Sache ist doch ein Nonsens" [Vada na ideálním podílu věci je přeci nesmysl].

75 Takto ale MÜLLER, Wilhelm. Die gemischte Schenkung. Jherings Jahrbücher für die Dogmatik des bürgerlichen Recbts. Band 48. Jena: Fischer, 1904, s. 218. Jeho argument dle zde zastávaného názoru neobstojí ani v německém právu (srov. \ 139 BGB). Na myšlenku vzájemnosti naráží i již obecnoprávní nauka (viz SAVIGNY, Friedrich Carl von. System des beutigen Römischen Rechts. Band 4. Berlin, 1841, s. 100).

76 Viz GOLDSCHMIDT, Siegfried. Die gemischte Schenkung nach Reichsrecht. Berlin: Verlag von Struppe \& Winckler, 1907, s. 42.

77 Takto SCHILLING. Lebrbuch der Institutionen, Band 3, s. 795. Cit. dle MÜLLER, Wilhelm. Die gemischte Schenkung. Jherings Jahrbücher für die Dogmatik des bürgerlichen Rechts. Band 48. Jena: Fischer, 1904, s. 220-221, pozn. pod čarou č. 24.

78 Viz GOLDSCHMIDT, Siegfried. Die gemischte Schenkung nach Reichsrecht. Berlin: Verlag von Struppe \& Winckler, 1907, s. 30. 
Někteří navrhovali, aby o určení rozhodoval obsah smlouvy a záměr stran. ${ }^{79}$ Jiní hodlali upřednostnit pravidla toho zákonného smluvního typu, který dominuje a nejlépe hájí zájmy stran. ${ }^{80}$ Reichsgericht ve své judikatuře dokonce zastával názor, že k určení smluvního typu je povolán soudce. ${ }^{81}$

Nutno podotknout, že určení smluvního typu dle dominance prvků úplatného či bezúplatného smluvního typu odpovídá tzv. absorpční teorii ${ }^{82}$ používané u tzv. smíšených smluv (tj. smluv, které jsou syntézou více zákonných smluvních typů, a to např. i jen úplatných [nap̌r. finanční či operativní leasing]).

Konečně se objevoval i názor, že v pochybnostech mají být upřednostněna pravidla o darování. ${ }^{83}$

Dle zde zastávaného názoru však nelze jednomu smluvnímu typu podřizovat in toto celý právní poměr, nebot’ takový závěr nerespektuje dvojí kauzu smíšeného darování.

„Strany nechtěji jen koupit nebo jen darovat, nechtěji jen jedno nebo jen drubé, nýbrž obojí, koupi i darováni." 84

Teorie jednoty zjevně redukuje dvě kauzy na jednu (zpravidla tu, která převažuje), a proto není schopna přinést řešení, které váží zájmy obou stran.

Sluší se poznamenat, že někteří autoři se sice hlásí k teorii jednoty, ale mají tím na mysli pouze to, že závazek má být uchopován jednotně, přičemž uznávají např. absorpční

79 Viz ENDEMANN, Friedrich. Lehrbuch des bürgerlichen Rechts. Band 1: Einleitung; allgemeiner Theil; Recht der Schuldverbältnisse. 6., nezměněné vyd. Berlin, 1899, s. 743.

80 Takto THUR, Andreas von. Der Allgemeine Teil Der Bürgerlichen Rechts. Band II/2, 1918, s. 76 a násl. Cit dle SCHLINKER, Steffen. Sachmängelhaftung bei gemischter Schenkung: - Aktuelle Fragen nach der Reform des Schuldrechts. Archiv für die civilistische Praxis. Tübingen: Mohr Siebeck, 2006, 206. Band, H. 1 (2006), s. 37.

81 Reichsgericht opřel svůj závěr o obrat „v pochybnostech“ vyskytující se v ALR (Das Allgemeine Landrecht für die Preußischen Staaten z r. 1794), konkrétně ALR I 11 \ 1053: „Schenkungen, welche unter einer von dem Geschenknehmer zu leistenden Bedingung, oder zu einem gewissen von ibm zu erfüllenden Endzwecke versprochen, oder gegeben worden, sind, im zweifelhaften Falle, den lästigen Verträgen gleich zu achten. "Dle citovaného ustanovení je třeba darování, která mj. podmiňují příjemce daru ke splnění podmínky nebo jsou přislíbena za to, pokud dárce dosáhne svým jednáním konečného účelu, posuzovat v pochybnostech jako úplatné smlouvy. Srov. rozhodnutí Reichsgerichtu ze dne 8. 6. 1880, ve věci hrabéte R. proti F. 168/80, publikovaný v časopise GRUCHOT, J. A. Beiträge zur Erläuterung des deutschen Rechts. Hamm: Grote. Jg. 25 = 3.F. Jg. 5 (1881), s. 435-436. Dostupné z: https://dlc.mpdl.mpg.de/dlc/view/escidoc:84619:2/ recto-verso;jsessionid=0224CBE5DFBFFB7AC9E52BFE1B048203

82 Viz ERTL, Gunter. In: FENYVES, Attila, Ferdinand KERSCHNER, Andreas VONKILCH et al. Großkommentar zum ABGB - Klang Kommentar. \938 bis 1001. 3. vyd. Wien: Verl. Österreich, 2013, \938, marg. ̌̌. 40.

83 Tak TUHR, Andreas von. AT II 21 S 72 II 3, 77 f. Cit. dle CHIUSI, Tiziana J. In: MARTINEK, Michael (red.). J. von Staudingers Kommentar zum Bürgerlichen Gesetzbuch. Buch 2, Recht der Schuldverbältnisse. \516-534 (Schenkungsrecht). Berlin: Sellier-de Gruyter, 2013, § 516, marg. č. 74.

84 Srov. GOLDSCHMIDT, Siegfried. Die gemischte Schenkung nach Reichsrecht. Berlin: Verlag von Struppe \& Winckler, 1907, s. 33. 
teorii či analogickou aplikaci pravidel o darování. ${ }^{85}$ Byt' označení „teorie jednoty“ se neužívá ,jednotně“، tak za účelem předejití nejasnostem s ní předkládaný text pojí zmíněné binární uvažování (tj. bud’ úplatná smlouva, nebo bezúplatná).

\subsection{Teorie o smlouvě sui generis}

Teorie o smlouvě sui generis se určitým zpo̊sobem blíží teorii jednoty v tom smyslu, že závazkový poměr nerozkládá na dvě části (takto teorie oddělenî), ale uchopuje jej jednotně.

Zmíněný přístup razil $W$. Müller, když se dovolával smluvní svobody o obsahu závazku. Smíšené darování je tak dle něj inominátem. Co tvoří lex contractus je v prvé radě otázkou ujednání stran. ${ }^{86}$ Absentuje-li, pak je třeba volit př́stup založený na analogii a obecných principech. ${ }^{87}$ Pravidla, jimiž se závazkový vztah bude řídit, tak budou určena prostřednictvím kombinace pravidel jednotlivých zákonných smluvních typů.

Podobný názor lze shledat i u Goldschmidta, ${ }^{88}$ jenž hovoří o smíšené smlouvě, v níž majî být aplikovány právní normy smluvních typů, které jsou v daném právním poměru smíšeny. Při kolizi odporujících si norem má být upřednostněna ta, která nejlépe odpovídá účelu smlouvy.

Tím, že jsou pravidla kombinována (zpravidla ustanovení o koupi a darovánî), je učiněno zadost, že se ve smluvním obsahu promítnou oba elementy. ${ }^{89}$ Nevýhodou tohoto př́stupu je, že nesklouzává k simplifikaci, a neredukuje tak právní problémy na část(i) řě̌ené dispozitivními normami kupní (a)nebo darovací smlouvy.

85 Tak např. Ehrenzweig píše, že nejde o přímou aplikaci, ale o analogickou, nebot’ soudce má volnou ruku v určení, která norma se na daný poměr použije. Analogická aplikace pravidel o darování však dle něj není použitelná tam, kde úplatnost převažuje, čímž akceptuje absorpční teorii (viz EHRENZWEIG, Armin a Josef KRAINZ. Der allgemeine Teil und das Sachenrecht. 5., zcela prrepracované vyd. Wien: Manzsche k. u. k. Hof-Verlags- und Universitäts-Buchhandlung, 1913, s. 327).

86 MÜLLER, Wilhelm. Die gemischte Schenkung. Jherings Jabrbücher für die Dogmatik des bürgerlichen Rechts. Band 48. Jena: Fischer, 1904, s. 226 a násl.

87 Ibid., s. 227.

88 Viz GOLDSCHMIDT, Siegfried. Die gemischte Schenkung nach Reichsrecht. Berlin: Verlag von Struppe \& Winckler, 1907, s. 35.

89 MÜLLER, Wilhelm. Die gemischte Schenkung. Jherings Jabrbücher für die Dogmatik des bürgerlichen Rechts. Band 48. Jena: Fischer, 1904, s. 228. 


\subsection{Teorie o hodnocení účelu}

Teorie o hodnocení účelu se v Německu a Rakousku stala převládajícím př́stupem k právnímu posouzení smíšeného darování. ${ }^{90,91}$ Oproti výše zmíněným teoriím odmítá podřizovat právní poměr konkrétnímu smluvnímu typu. Z hlediska flexibility jednotlivého prŕpadu pak má být ponecháno otevřené, která norma bude aplikována. Výchozím kritériem aplikace je ta norma, která nejlépe odpovídá účelu nebo vưli stran. Podle $\mathrm{BGH}^{92}$ „stojí v poprèdí hospodárský účel právníbo jednání prí zoblednèni oboustranných zájmui."

\subsection{Názory české nauky}

\subsubsection{Prvorepubliková nauka}

Podle Sedláčka je „nejlépe [...] považovati celé jednáni za celek a od prípadu k prípadu je podríditi bud' ustanovením o smlowvách vájemných anebo ustanovením o darováni podle toho, co bude vhodnèjši. "93 Forma notářského spisu, kterou v té době vyžadovala pravidla o darování, se má použít tehdy, je-li hodnota jednoho plnění bezvýznamná ve vztahu k druhé. Zda jde o objektivní, či subjektivní ekvivalenci, není z autorova výroku zřejmé. Pravidla o odvolání daru se dle něj mají použít jen na tu část, která je bezúplatná dle subjektivní ekvivalence. Konečně je dle Sedlačka možné rozdělit jednotné hospodářské jednání ve dvě právní jednání. ${ }^{94}$

Sedláckovy závěry vyvolávají mnohé nejasnosti, nebot' se v nich mísí snad všechny teorie. $\mathrm{Na}$ jednu stranu se zdá, že upřednostňuje teorii jednoty, leč v určitých aspektech tíhne i k teorii oddělení. Není kupř́ikladu zjevné, zda oním obratem „od případu k případu“ má na mysli zvažování aplikovatelnosti jednotlivých norem, či celých normových komplexů zákonných smluvních typů; jinými slovy, zda podřizování zákonnému smluvnímu

90 Srov. CHIUSI, Tiziana J. In: MARTINEK, Michael (red.). J. von Staudingers Kommentar zum Bürgerlichen Gesetzbuch. Buch 2, Recht der Schuldverhältnisse. \516-534 (Schenkungsrecht). Berlin: Sellier-de Gruyter, 2013, \516, marg. č. 76; KOCH, J. In: WESTERMANN, H. P. a kol. Münchener Kommentar zum Bürgerlichen Gesetz̧buch. Band 4. Schuldrecht - Besonderer Teil I $\int 433-534$ Finanzierungsleasing CISG. 8. vyd. München: C. H. Beck, 2019. Dostupné z: Beck-online.de. BGB, 』516, marg. č. 38; GEHRLEIN, Markus. In: HAU, Wolfgang, Roman POSECK et al. Beck'sche Online Kommentar BGB. Stav: 56. Ed. 1. 11. 2020. Dostupné z: Beck-online.de. BGB, \516, marg. č. 14.

91 Podobně i v rakouské vědě se hovoří o tzv. kombinační teorii, kdy se pro každou povinnost plnit určuje věcně nejvhodnější ustanovení. Z hlediska metodologické pregnance ji Ertl označuje jako teorii analogické aplikace práva (viz ERTL, Gunter. In: FENYVES, Attila, Ferdinand KERSCHNER, Andreas VONKILCH et al. Großkommentar zum ABGB - Klang Kommentar. 938 bis 1001. 3. vyd. Wien: Verl. Österreich, 2013, § 938, marg. č. 40).

92 Rozhodnutí BGH ze dne 23. 5. 1959, sp. zn. V ZR 140/58, publik. v Neue Juristische Wochenschrift, roč. 1959, s. 1363.

93 Viz SEDLÁČEK, František. In: ROUČEK, František, František SEDLÁČEK et al. Komentář ke čskoslovenskému obecnému zákoníku občanskému a občanské právo platné na Slovensku a v Podkarpatské Rusi. Díl čtvrtý,

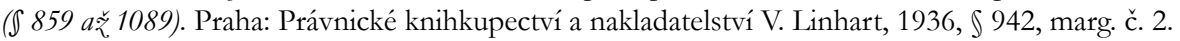

94 Viz Ibid., \ 942, marg. č. 4. 
typu se děje en bloc pro celou smlouvu, nebo zvlášt' u každého smluvního ujednání. K otázce vad se citovaný autor vůbec nevyjadřuje. Zda je Sedláčkio prístup ve své podstatě schizmatický, nebot' nejprve zdůrazňuje dvojí kauzu, ${ }^{95}$ ale posléze prostřednictvím absorpce připouští jednu upozaděním jedné z nich, zůstává př́liš nejasné. Obecně nelze přitakat ani rozložení smíšeného darování do dvou právních jednání, ledaže by se jednalo o výše zmiňovaný př́pad tzv. mnohosti smluv.

\subsubsection{Aktuálni názory české nauky}

D. Elischer ve své habilitační práci stran právního posouzení smíšeného darování uvádí: ${ }^{96}$ „Na smísenou smlouvu se budou aplikovat ustanoveni o darováni se v'̌emi dìsledky jen $v$ tom rozsabu, vjakém hodnota plnèni prevyšuje poskytovanou úplatu, tj. na to, co je skutečným darovánim, a ve zbytku se smlowva posoudi podle jiných prìslušných ustanoveni (kupr. o kupní, smènné smlouvě-práva z vadnébo plnèni, odstoupeni od smlouvy, splatnost atp., anebo se v relevantní míre aplik.uji ustanoveni o služebnostech, výmènku, díchodu apod.)."

Podaným vymezením se autor nejspíše hlásí k teorii oddělení. Nadto se sluší poznamenat, že se nepodává jakákoliv bližší argumentace a výše zmíněný názorový vývoj je habilitací zcela ignorován.

M. Janoušek ${ }^{97}$ se defaultně přiklání k teorii o hodnocení účelu, přičemž lakonicky dodává, že teorie jednoty se použije na otázku formy, teorie oddělení na kolaci a práva z vadného plnění či odvolání daru. Citovaný autor ale již dále nerozvádí, jak se mají pravidla přesně aplikovat.

Záhodno je třeba dodat, že teorie oddělení je bez dalšího rozvedení nepoužitelná. Jestliže totiž na věci lpí vada, jak se má právní posouzení dále ubírat? 'Týká se vada té části, o níž byla uzavřena ona pomyslná kupní smlouva, nebo vice versa darovací smlouva? Spočívá-li vada totiž v bezúplatné části, nemůže být o právech z vad řeč (viz 1.2). Jestliže dospějeme k závěru, že se týká úplatné části, pak nejsou zcela zřejmé důsledky práv z vad. Držíme-li se zmíněného závěru, pak odstoupením od smlouvy z důvodu vadného plnění vznikne k věci spoluvlastnictví, ${ }^{8}$ nejsou-li splněny předpoklady \2065 v. 3 OZ, aby obdarovaný mohl odstoupit též od darovací smlouvy. Odstoupení od smlouvy ve vztahu k plněné

95 Viz SEDLÁČEK, František. In: ROUČEK, František, František SEDLÁČEK et al. Komentár k československému obecnému zákoníku občanskému a občanské právo platné na Slovensku a v Podkarpatské Rusi. Díl čtvrtý,

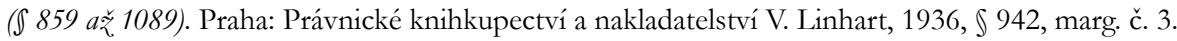

96 Takto ELISCHER, David. Darováni a jeho podoby v novém soukromém právu. Praha: Wolters Kluwer, 2016, s. 37; Podobně i starší rakouská judikatura OGH SZ 5/42, která však byla později překonána (viz níže).

97 Viz JANOUŠEK, Michal. In: PETROV, Jan et al. Občanský qúkoník: komentár. Praha: C. H. Beck, 2017, \ 2055, marg. č. 18.

98 Zmíněný právní následek vychází z věcněprávních účinků odstoupení od smlouvy, což odpovídá české nauce (za všechny ŠILHÁN, Josef. In: HULMÁK, Milan et al. Občanský zákoník V. Závažkové právo. Obecná část (』 1721-2054). Praha: C. H. Beck, 2014, \2005, marg. č. 12). Tento závěr zde není kriticky hodnocen. 
věci tak má parciální právní následky. Problematické je i provedení slevy z ceny. Jestliže věc v hodnotě 100 je koupena za poloviční cenu a současně za poloviční cenu darována, přičemž v okamžiku předání vykazuje vadu, jež snižuje hodnotu věci na 90 , tak by měla být cena snížena o 5?

Podané aspekty svědčí o tom, že autory zastávaná dělící nauka není bez dalších navazujících úvah přímo použitelná. Již začátkem 20. stol. se o ní ostatně suverénně v rakouské nauce psalo jako o staré překonané koncepci, ${ }^{99,100}$ kdežto v německé již byla dávno argumentačně odmítnuta.

Lze tedy uzavřít, že doposud není podán uspokojivý výklad, jakým způsobem mají být řešeny následky vadného plnění u smíšeného darování. Současné publikované názory se tak spíše kolem problému „točí“ a řešení jimi navržená vzbuzují nejasnosti o jejich aplikovatelnosti.

\subsection{Vlastní stanovisko}

Teorie o hodnocení účelu představuje adhocistní právní posouzení, a proto není s to nabídnout obecně platné poznatky, jak má být určitá otázka in abstracto řešena. Jestliže se zde hodlá předložit defaultní právní posouzení, jak přistupovat k odpovědnosti zcizitele za vady, nelze z ní zákonitě vycházet.

Odmítnout je třeba parcelaci závazku (teorie oddělenî), která rozčleněné části podřizuje jednotlivým smluvním typům, nebot' sama o sobě není účelná a žádné řešení nenabízí. Záhodno je zavrhnout i teorii jednoty, která stojí na podř́zení závazku jedinému smluvní typu, čímž upozadí jednu z kauz (k nedostatkům obou teorií viz 3.2, 3.3).

Zde zastávaný názor se kloní k teorii o smlouvě sui generis. Tento př́ístup je následováníhodný proto, že jen takto lze dosíci zohlednění dvojí kauzy vyskytující se v jedné obligační smlouvě. Přitakává se poznatku, že smíšené darování je inominátní smlouvou kombinující více zákonných smluvních typů, event. že jde o smíšenou smlouvu.

Rozhodování o tom, které z pravidel zákonného smluvního typu se použije, nemůže být jiné než při rozhodování dle pravidel tzv. doplňujícího výkladu. ${ }^{101} \mathrm{Na}$ právní poměr se tak mají aplikovat pravidla získaná analogií a z obecných principů, přičemž musí co nejlépe odpovídat vưli stran.

99 Viz EHRENZWEIG, Armin a Josef KRAINZ. Der allgemeine Teil und das Sachenrecht. 5. zcela přepracované vyd. Wien: Manzsche k. u. k. Hof-Verlags- und Universitäts-Buchhandlung, 1913, s. 327; pozdejii, ale taktéž i STANZL, Gustav. In: KLANG, Heinrich, Franz GSCHNITZER et al. Kommentar zum Allgemeinen bürger-

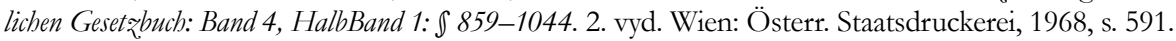

100 Judikatura OGH se od ní proto později odklonila (srov. rozhodnutí OGH ze dne 14. 3. 1979, sp. zn.

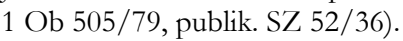

$101 \mathrm{~K}$ doplňujícímu výkladu v podrobnostech srov. KOTÁSEK, Josef. Doplñujicí výklad smlouvy. Brno: Masarykova univerzita, 2018; MELZER, Filip. In: MELZER, Filip, Petr TÉGL a kol. Občanský zákoník: velký komentár. Svazele III, \419-654 a souvisejici spolećná a prechodná ustanovení. Praha: Leges, 2014, komentář k $\int 545$. 
Tímto prizmatem může být využita i absorpční metoda, odpovídá-li hypotetické vưli stran. Je-li dokazováním postaveno najisto, že určitý aspekt v daném smluvním poměru převažoval v takové míře, že dle hypotetické vưle stran podávající se $z$ doprovodných okolností by jeden ze dvou zákonných smluvních typů měl druhému en bloc ustoupit, lze využít myšlenky absorpční metody. Tento závěr však nelze učinit jen na základě toho, že věc byla darována jen v minimálním poměru oproti koupi. Bezpochyby však může jít o silnou indicii (čím vyšší nepoměr, tím významnější indicie) ospravedlňující takovou hypotetickou vưli, a absorpce tak může být vhodným řešením. Totéž platí samozřejmě i obráceně (tj. darováno bylo jen v nepatrném rozsahu).

$\mathrm{V}$ řadě případů však absorpci užít nelze a je potřeba se ptát, která pravidla a kterého smluvního typu se mají aplikovat. Dle zde zastávaného názoru je třeba vyjít z abstraktního vážení zájmů, jež lze učinit na podkladě dispozitivních pravidel. Tato pravidla mohou být však upozaděna autonomií vưle stran. Existují-li zvl. smluvní ujednání, která vyžadují doplnění, pak je třeba vážení zájmů kombinovat jednak s tím, co plyne z dispozitivních norem, jednak co z ujednání stran.

Tam, kde ustanovení o darovací smlouvě stanovují s ohledem na princip utility (viz 1.2) odlišná pravidla od kupní smlouvy (či jiného úplatného zákonného smluvního typu), jež zase vychází ze synallagmatické povahy primárních povinností plnit, je třeba poměřovat v kolizi stojící zájmy, a vymezit tak základní předpoklady aplikace institutu odpovědnosti za vady, odvolání daru etc.

Výklad dále podaný vychází čistě ze zájmů sledovaných dispozitivními pravidly. Jestliže tak in concreto bude smluvní ujednání některé z dispozitivních pravidel přetvářet, je třeba tyto okolnosti vzít v potaz a spolu s dispozitivními pravidly opět poměřit v kolizi stojící zájmy. Dále představené úvahy se týkají výlučně problematiky práv z vad.

\section{Narušení ekvivalence jako předpoklad práv z vad smíšeného darování}

V literatuře se vyskytuje názor, že je-li plnění u smíšeného darování nedělitelné, rozhoduje o aplikaci práv z vad to, v čem leží jeho těžiště. ${ }^{102}$ Dle této koncepce, opírající se o teorii jednoty (viz 3.3), by tak byla ustanovení \ 1914 an. OZ (2099 an. OZ) přímo použitelná, a to en bloc bez jakéhokoliv omezení. Tomuto prrístupu se zde však nepřitakává (viz 3.7), leč v rámci části věnované realizaci prostředků nápravy se poukazuje i na jím zastávané řešení.

Pro zde zastávané stanovisko je z hlediska práv z vad určující, že výsledkem doplňujícího výkladu musí být taková konstelace práv a povinností závazku, která váží zájmy obou stran. Je tak třeba sloučit pravidla, jež se zdají být na první pohled nesjednotitelná,

102 Takto CHIUSI, Tiziana J. In: MARTINEK, Michael (red.). J. von Staudingers Kommentar zum Bürgerlichen

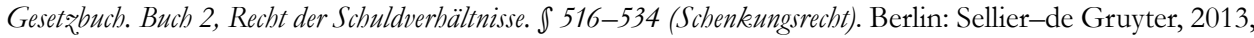
\516, marg. č. 84. 
nebot' zatímco zcizitele, jenž převedl lukrativně (bezúplatně), povinnosti z vad nestíhají, tak toho, jenž převedl onerózně (úplatně), zase ano. ${ }^{103}$

Tato poznámka není bez významu, nebot' někteří autoři sice chápou smíšené darování jako smlouvu sui generis, přesto však svévolně a eklekticky některé prostředky nápravy vadného plnění prrijímají, jiné odmítaji. ${ }^{104}$ Takový názor však není hoden následování, nebot', jak je dále vylíčeno, lze s pomocí vážení zájmů najít vybalancované řešení.

Uvědomění si účelu a smyslu práv z vad je určujícím motivem prozařujícím dále podaným výkladem. Jestliže funkcí práv $z$ vad je vyrovnat narušenou subjektivní ekvivalenci (viz 1.1), pak u smíšeného darování nastává narušení jen částečné (jen částečně se plní úplatně). Z toho pak plyne, že myšlenka narovnání narušené ekvivalence se má odehrávat jen $\mathbf{v}$ té míře, $\mathbf{v}$ jaké byla narušena. O právech $z$ vad lze tak konsekventně uvažovat až tehdy, klesne-li hodnota předmětu plnění pod subjektivní ekvivalenci úplatné části. ${ }^{105} \mathrm{~V}$ tomto ohledu nedochází $\mathrm{k}$,pparcelaci“ smlouvy (takto teorie oddělení [viz 3.2]), nýbrž nastává parcelace předpokladů práv z vad.

Práva z vad mohou najít uplatnění až tehdy, jestliže hodnota plnění zcizitele nedosahuje úplaty poskytnuté nabyvatelem, a to dle pravidel subjektivní ekvivalence. Až tehdy vystupuje do popředí myšlenka narušené ekvivalence. ${ }^{106}$ Jinými slovy, věcná působnost odpovědnosti za vady vyžadující plnění za úplatu (srov. \1914 odst. 1 OZ) není jinak dána.

P̌. č. 1: Věc v hodnotě 100 (objektivni ekvivalence), má pro strany bodnotu 120 (subjektivní ekvivalence), pričemž prostrednictvím jediné smlouvy je z.poloviny tak.to vymezené hodnoty darována a z drubé prodána. Jestližze za tèchto okolnosti neklesne objektivni hodnota véci pod 50 (musi se zachovat pomèr subjektivni ekvivalence!!], který mérime objektivni hodnotou), neni dán predpoklad práv z. vad.

Podané řešení náležitě hájí zájmy stran. Zájem nabyvatele na ekvivalenci plnění je totiž uplatnitelný jen v té míře, ve které je současně zachován zájem zcizitele nebýt povolán

103 Pokud jsou naplněny hmotněprávní předpoklady \2065 OZ, pak zabývat se odpovědností za vady dle \} 1 9 1 4 \text { an. OZ ztrácí na významu. Relevantní jsou tudíž zejména situace, kdy plnění dárce nezakládá } práva ve smyslu \ 2065 OZ.

104 Např. Goldschmidt sice obecně přiznává práva z vad, ale odmítá připustit právo na přiměřené snížení ceny, když uvádí, že to neodpovídá účelu závazku. Naproti tomu bez okolků připouští odstoupení od smlouvy (viz GOLDSCHMIDT, Siegfried. Die gemischte Schenkung nach Reichsrecht. Berlin: Verlag von Struppe \& Winckler, 1907, s. 59-60).

105 Takto i KOCH, Jens. In: WESTERMANN, Harm Peter et al. Münchener Kommentar zum Bürgerlichen Gesetz̧buch. Band 4. Schuldrecht - Besonderer Teil I \433-534 Finanzierungsleasing CISG. 8. vyd. München: C.H.Beck, 2019. Dostupné z: Beck-online.de, BGB, \516, marg. č. 44; SCHLINKER, Steffen. Sachmängelhaftung bei gemischter Schenkung: - Aktuelle Fragen nach der Reform des Schuldrechts. Archiv für die civilistische Praxis. Tübingen: Mohr Siebeck, 2006, 206. Band, H.1 (2006), s. 46.

106 Srov. EHRENZWEIG, Armin a Josef KRAINZ. Der allgemeine Teil und das Sachenrecht. 5. zcela přepracované vyd. Wien: Manzsche k. u. k. Hof-Verlags- und Universitäts-Buchhandlung, 1913, s. 327; shodně WELSER, Rudolf a Brigitta ZÖCHLING-JUD. Bürgerliches Recht II. 14. vyd. Wien: Manz, 2015, marg. č. 863. 
k odpovědnosti za vady, jestliže ekvivalence narušena nebyla. Neklesla-li v důsledku vady objektivní hodnota věci pod zobjektivizovanou hodnotu věci, která měla být dle vůle stran darována, tak není narušen zájem zcizitele na obdržení ekvivalentního plnění.

Takto vymezený přístup je zde zastáván jako výchozí předpoklad myslitelné odpovědnosti za vady. Jak se dále poznamenává, někteří autoři jej vyžadují jen u určitých prostředků nápravy z vad (např. názory v německé nauce jej pomíjí u vady zakládající právo odstoupit od smlouvy).

\section{Vyrovnání ekvivalence jako následek práv z vad smíšeného darování}

V předchozí pasáži dovozený závěr se promítá i do toho, co lze maximálně nárokovat prostřednictvím práv z vad. ${ }^{107}$ Nabyvatel nemưže být stavěn do takové pozice, $\mathrm{v}$ jaké by byl, kdyby jak plnění oproti protiplnění, tak plnění bez protiplnění odpovídalo smluvně ujednanému. Smluvně ujednanému musí plnění odpovídat jen do míry protiplnění, a to ve smyslu subjektivní ekvivalence. ${ }^{108}$ Narušená subjektivní ekvivalence má být totiž napravena jen v míre narušení.

V rámci smlouvy o dílo, kde je dluhován výsledek, je třeba vycházet z hodnoty výsledného díla v poměru k jeho obvyklé ceně. ${ }^{109}$ Jestliže zhotovitel staví z materiálu objednatele, přičemž plnění poskytuje částečně bezúplatně, pak rozhodující bude hodnota zhotovení.

Pr. č. 2: Trublár vyrábi skrín v hodnotě 250, a to z materiálu v hodnotě 100, který mu dodal objednatel. Obvyklá cena za zhotoveni díla, která odpovídá též subjektivni ekvivalenci stran, činí 100, nicméně trublár plní v puilce bezúplatně a v puilce úplatně. Vyrobená skerín však je vadná a má jen hodnotu 130.

$\mathrm{V}$ daném prrípadě je dána odpovědnost zcizitele nikoliv do plné obvyklé hodnoty plnění, nýbrž jen do té části, v jaké je narušena ekvivalence. Prostřednictvím práv z vad tak nemůže nabyvatel požadovat, aby vada byla odstraněna tak, že získá plnou hodnotu zhotovené věci (tj. 250), nýbrž aby měla hodnotu 175. Bezvadné plnění má totiž navýšit hodnotu ze 100 na 250 (tj. o 150), přičemž takové plnění ze strany zhotovitele má obvyklou hodnotu 100 (zde pro zjednodušení též i subjektivní hodnotu). Je-li však v rámci poloviny plněno bezúplatně, pak lze o vadě zakládající odpovědnost za vady hovořit

\footnotetext{
107 Opačně ale Michel, jenž uváděl, že zákon (ABGB) vyžaduje pouze úplatnost, nikterak to, aby vzájemná plnění musela vůči sobě stát $\mathrm{v}$ určitém poměru nebo mít shodnou obvyklou cenu. Citovaný autor proto se smíšeným darováním automaticky pojil pravidla o právech z vad, aniž by dovozoval jakékoliv omezení. Srov. v podrobnostech MICHEL, Adalbert Theodor. Darstellung der Gewährleistung nach dem österreichischen Privatrecbte. Prag: von Friedrich Rohljček, 1849, s. 5-6.

108 Výchozí je totiž maxima, že práva z vad slouží k vytvoření subjektivní hodnotové relace plnění, jež mělo být dodáno (viz 1.1).

109 I zde je pochopitelně rozhodující subjektivní ekvivalence, z důvodu zjednodušení však presumujeme, že odpovídá objektivní ekvivalenci.
} 
tehdy, jestli nedošlo k navýšení alespoň o poloviční hodnotu (tj. o 75). Z toho se podává, že subjektivní ekvivalence je v uvedeném př́kladu narušena ve výši 45 (= 175 - 130). ${ }^{110}$

Obecnou funkci práv z vad, tj. narovnání narušené subjektivní ekvivalence, nezbývá než promítnout i do smíšeného darování. Požadovatelná míra vyrovnání narušené subjektivní ekvivalence je tudíž prostřednictvím práv z vad předurčena mírou narušené ekvivalence. ${ }^{111}$ Tj. plnění musí být uvedeno do takového stavu, kdy již není dán předpoklad narušené ekvivalence (viz 4).

Je nabíledni, že některá práva z vad (oprava věci, či dodání toho, co chybî) budou zř́idkakdy realizovatelná tak, aby došlo jen $\mathrm{k}$ nápravě v míre narušené ekvivalence, a nabyvatel tak neposkytl ani více, event. ani méně. Tuto skutečnost je však třeba zohlednit při komplexní aplikaci těchto práv z vad (blíže sub 6.2). V rámci odstoupení od smlouvy je nutno na tento aspekt rezignovat, nebot' tento právní prostředek nápravy se promítá do celého závazku (srov. 6.4), jinak by bylo třeba od tohoto práva upustit.

\section{Realizace prostředků práv $\mathrm{z}$ vad}

V níže rozebíraných částech se postupně zkoumá způsob uplatnění jednotlivých práv z vad a pro názornost se jednotlivé obecné poznatky demonstrují na konkretizovaných případech kupní smlouvy, jakožto modelovém úplatném zákonném smluvním typu. Tytéž závěry se však mutatis mutandis uplatní i tam, kde zákonný smluvní typ v úplatné části nevykazuje znaky kupní smlouvy, ale nap̌r. směny, nebo výměnku ${ }^{112}$ aj.

\subsection{Analogická aplikace pravidel normujících obecné znaky skutkové podstaty vadného plnění a uplatnitelnosti práv z vad}

Mimo rámec poznatků uvedených sub. 4, 5 se uplatní shodná pravidla pro určení, zda je poskytnuté plnění vadné. Pro kvalifikaci vady je tak rozhodující subjektivní,

110 Zmíněný přístup není pochopitelně uplatnitelný v situacích, kdy plnění zhotovitele samo o sobě není hospodářsky účelné (např̀. přelakování auta na jinou barvu z důvodu čistě osobních preferencí objednatele). V takovém př́padě nezbývá než aplikovat \136 OSŘ. S ohledem na panující judikaturu se však bude vyžadovat, aby nabyvatel prokázal, že došlo k narušení ekvivalence. Srov. rozsudek Nejvyššího soudu ze dne 5. 12. 2016, sp. zn. 23 Cdo 2406/2016, či usnesení Nejvyššího soudu ze dne 28. 7. 2020, sp. zn. 32 Cdo 1044/2020, dle nichž musí být prokázán základ nároku, přičemž dle $\int 136$ OSŘ se určuje jen jeho výše.

111 Shodně, ale jen pro některé prostředky nápravy vadného plnění též SCHLINKER, Steffen. Sachmängelhaftung bei gemischter Schenkung:-Aktuelle Fragen nach der Reform des Schuldrechts. Archiv für die civilistische Praxis. Tübingen: Mohr Siebeck, 2006, 206. Band, H.1 (2006), s. 45.

112 Právě smlouva o výměnku často v právní praxi představuje případ smíšeného darování, nebot' výměnkář této právní konstrukce užívá jako tzv. anticipované dědické posloupnosti (v podrobnostech SAURER, René. In: GRUBER, Michael et al. Erbrecht und Vermögensnachfolge. Wien: Springer, 2010, § 3, s. 41 a násl.), a proto výměnkáře jako zcizitele mohou stíhat povinnosti z vad. Zejména $\mathrm{v}$ situacích tzv. anticipované dědické posloupnosti přitom bude připadat $\mathrm{v}$ úvahu využití absorpční metody, a bude lze tak dovodit př́mou aplikovatelnost ustanovení o darovací smlouvě. 
subjektivně-objektivní a objektivní vadný pojem (viz 1.1). ${ }^{113}$ Významné nadále bude, zda vada byla dle $\int 1917$ v. 1 OZ zjevná při uzavírání smlouvy (tzv. vady bijící do očí) či též zda strany vyloučily práva z vad (\$ 1916 odst. 2, \1918 OZ). Obdobně se uplatní pravidla týkající se procedurálního uplatnění práv z vad (kupř. vytýkací povinnost zcizitele dle \1921 odst. 1 OZ). Povaha smíšeného darování dle zde zastávaného názoru sama o sobě není způsobilá odůvodnit, proč by se tyto aspekty měly ř́́dit odlišnými pravidly.

Z hlediska uplatnění práv z faktických vad se použije pravidlo ohledně vytýkací povinnosti, jejíž nesplnění zakládá zciziteli právo namítnout opožděné vytknutí (『1921 odst. 3 v. 1 OZ). Stejně tak se uplatní pravidlo, dle něhož se ke zmeškání vytýkací povinnosti nepřihlédne, jestliže je vada důsledkem skutečnosti, jež musela být zciziteli při předání známá (\} 1 9 2 1 \text { odst. } 3 \text { v. 2, \} 2 1 1 2 \text { odst. } 2 \text { v. } 2 \text { OZ). }

Bez výjimky se použije i \1924 OZ zakotvující nabyvateli právo na náhradu účelně vynaložených nákladu při uplatnění práva z vad.

Charakterem částečné bezúplatnosti nelze odůvodňovat, že mají být brány v potaz jen některé typy vad. Stejně tak nelze říci, že strany implicitně vyloučily práva z vad, že má být kratší promlčecí lhůta práv z vad, nebo kratší objektivní lhůta pro splnění vytýkací povinnost atd. Tato pravidla se uplatňují jen za výše uvedených podmínek (sub 4, 5), nebot' blíže definují, co narušením ekvivalencí je, a co nikoliv, příp. jakým postupem se práva z vad uplatňují. Jde o pravidla, která dle zde zastávaného názoru nelze a ani není třeba přes vážení zájmů „překonstruovávat“.

Analogickou aplikaci pravidel o uplatnění práv z vad lze podpořit též tak, že zkracování vytýkací lhůty zcizitele $z$ důvodu smíšeného darování dle poměru úplatné a bezúplatné části nedává dobrý smysl. Je tomu tak proto, že jde o pravidla, která reflektují důkazní obtíže zcizitele spojené s tím, že s odstupem času je volán k odpovědnosti za vady předmětu plnění, který se již notnou dobu nenachází v jeho sféře; ergo není zde dána jakákoliv souvislost s částečnou (bez)úplatností. Poměrné krácení lhůt pod rouškou ,,adaptace pravidel“ (např. věc je zcizena za polovinu subjektivní ekvivalence, a proto má být poloviční lhůta pro vytknutí vady) tudíž není plauzibilní způsob promítnutí povahy smíšeného darování. Krátké vytýkací lhůty ostatně zohledňují i aspekt, že fáze realizace závazku sleduje rychlý průběh smlouvy. ${ }^{114}$ Ani s tím však nemá částečná bezúplatnost co do činění.

Naproti tomu až konkrétní práva z vad, která určují následky vadného plnění, již přímo působí na rozsah napravení narušené ekvivalence. Konstruovány jsou totiž tak, že plnění má být zcizitelem narovnáno do podoby smluvně ujednané (bezvadné). Plná náprava

113 Srov. k pojmům GREINER, Stefan. Schuldrecht Besonderer Teil: Vertragliche Schuldverhältnisse. 2. vyd. Berlin: Springer, 2019, s. 20 a násl.

$114 \mathrm{~K}$ podrobnostem a využití této hodnoty srov. vč. dalších odkazů též KOLMAČKA, Viktor. Ke vztahu práv z vadného plnění a omylu o vlastnostech předmětu koupě. Právní roz̧̧ledy, 2020, č. 7, sub V.2. 
do bezvadné podoby však není se smíšeným darováním slučitelná, nebot' neguje zájmy bezúplatného zcizitele, kterého povinnosti z vad nestíhají (sub 1.2).

\subsection{Oprava věci a dodání toho, co chybí}

Předpokladem obou prostředků nápravy z vad je odstranitelnost vady, mutatis mutandis „dodatelnost“ chybějícího (\$ 1923 v. 1 in principio OZ). Při využití těchto prostředků nápravy vad je však třeba dodržet požadavky zmíněné sub 4 a 5 , tedy že oba prostředky jsou použitelné jen při narušení ekvivalence a v mezích odstranění toho narušení.

\subsubsection{Oprava véci}

Problémy nevznikají tam, kde oprava vede k vyrovnání narušené ekvivalence, aniž by zcizitel odstranil více, či méně, než měl. Takové př́pady se však budou v právním styku vyskytovat zřídka.

Častější bude spíše situace, kdy na věci lpí vada, jejímž odstraněním by zcizitelem poskytnuté plnění přesáhlo hodnotu, za kterou bylo poskytnuto ekvivalentní protiplnění. Odstranění vady pak bude znamenat více než pouhé vyrovnání narušené ekvivalence. $\mathrm{V}$ tomto ohledu je třeba opět vážit zájmy obou stran a dle účelu smlouvy (zde dvojí kauzy) konstruovat zpo̊sob, jakým se má oprava uskutečnit. Myslitelná varianta, kvalifikovat takovou vadu a priori jako neodstranitelnou, je dle zde zastávaného názoru pro svoji neúčelnost zavrženíhodná.

Předně má zde zastávaný názor za to, že lze využít zobecnitelného pravidla \2106 odst. 2 v. 3 OZ (odmítnutí odstranění vady). Zcizitel je oprávněn nabyvateli prohlásit, že odmítá vadu odstranit, a proto přichází in eventum do úvahy další prostředky nápravy, a to bud' odstoupení od smlouvy, nebo přiměřená sleva z ceny (arg. leg. cit. „mưře kupujici požadovat misto odstranèni" “). Byt' se citované pravidlo neobjevuje v obecné části závazkového práva (tj. \1914 an. OZ), pak z hlediska hodnotově koherentního výkladu se jeví jako přiléhavý postup dovodit jeho analogickou aplikaci. Neshledává se, v čem by povaha kupní smlouvy vykazovala odchylky ospravedlňující odlišný postup. Význam odmítnutí odstranit vadu totiž vede $\mathrm{k}$ tomu, že nabyvatel není vázán výběrem původně zvoleného prostředku nápravy.

Jestliže zcizitel vadu odstraní, pak se jeví jako sporné, zda má právo na náhradu nákladů v té části, která přesáhla ekvivalentní část plnění. Opravit věc v té míře, aby již nebyla narušena ekvivalence, je spíše uskutečnitelné v teoretické abstraktní rovině než prakticky proveditelné. $\mathrm{V}$ tomto ohledu je však třeba se držet mantinelu, že vyrovnávána má být jen narušená subjektivní ekvivalence (zájem zcizitele). Řešení se shledává v nároku zcizitele na vynaložené náklady, opřené o \2436 OZ př́íkazní smlouvy. 
Může se jevit jako sporné, zda s takovou opravou věci musí souhlasit předem obě strany (tj. řešení ve formě privativní novace) ${ }^{115}$ nebo je zcizitel automaticky k opravě povinen, nicméně nárok je prosaditelný jen oproti nároku na vynaložené náklady na vynaložené náklady (aspekt funkčního synallagma).

Rakouská nauka u opravy předmětu koupě, skrze kterou je zvýšena hodnota věci v kontrastu věci bezvadné, pripouští vyrovnání výhody (Vorteilsausgleichung), kterou nabyvatel odstraněním vady získá. Předpokladem však pochopitelně je, že nabyvatel souhlasí s tím, aby mu zcizitel plnil nad rámec toho, co bylo pưvodně sjednáno, ${ }^{116}$ a že s ohledem na výklad smlouvy, vč. tzv. doplňujícího výkladu, nelze opravenou věc kvalifikovat jako plnění dle původní smlouvy. V opačném případě by totiž nebylo lze hovořit o vyrovnání obohacení. ${ }^{117}$ Odpovídá-li totiž opravený předmět plnění původní smlouvě, tj. původně (ne)sjednaným vlastnostem, pak zciziteli nárok na vyrovnání výhody nemůže náležet, nebot' by v podstatě nastalo odstranění odstranitelné vady. Dle jednoho z názorů se vyrovnání výhody má odehrávat dle pravidel „,nové za staré“. ${ }^{118}$ Pro prúpady takové opravy věci je však př́značné, že nastává privativní novace, nebot’ namísto pưvodně uplatněného nároku (oprava věci) získává věřitel za konsensu stran hodnotnější plnění. Jestliže by však dlužník (zcizitel) tímto způsobem odstranil vadu bez vědomí věřitele (nabyvatele), pak jde o problém vnuceného obohacení. ${ }^{119}$ Tyto názory jsou následováníhodné i v české nauce. I u smíšeného darování dochází k takové změně, nebot' bez dohody o príkazu nelze dovodit, že zcizitel musí odstranit vadu i v té míře, kde nebyla poskytnuta protihodnota. Myšlenkou práv z vad (viz 1.1) není možné odůvodnit řešení, že zcizitel je bez předchozí dohody stran povinen plnit oproti nároku na vynaložené náklady, a proto absentuje též ochrany hodný zájem nabyvatele, který by ospravedlnil uložení takové povinnosti zciziteli. $V$ takovém případě by zcizitel ani navíc nemohl předem požadovat zálohu.

Zde zastávaný názor vychází z toho, že uplatnění opravy věci je při souhlasu stran kombinováno s bezúplatným př́ḱkazem ( $\int 2430$ an. OZ), s nímž právní úprava pojí nejen nárok na náhradu nákladı̊, ale také i právo požadovat zálohu (\2436 OZ). ${ }^{120}$ Nárok

115 Takto SCHLINKER, Steffen. Sachmängelhaftung bei gemischter Schenkung: - Aktuelle Fragen nach der Reform des Schuldrechts. Archiv für die civilistische Praxis. Tübingen: Mohr Siebeck, 2006, 206. Band, H.1 (2006), s. 48; jej následuje KOCH, Jens. In: WESTERMANN, Harm Peter et al. Münchener Kommentar zum Bürgerlichen Gesetz̧buch. Band 4. Schuldrecht - Besonderer Teil I I 433-534 Finanzierungsleasing CISG. 8. vyd. München: C. H. Beck, 2019. Dostupné z: Beck-online.de. BGB, J 516, marg. č. 44.

116 Viz KREJCI, Heinz. Reform des Gewährleistungsrechtes. Verlag Österreich, 1994, s. 108-109.

117 Takto JUD, Brigitta. Schadenersatz bei mangelhafter Leistung. Wien: Manz Verlag, 2003, s. 166.

118 Viz OFNER, Helmut. In: KODEK, Georg et al. ABGB: Praxiskommentar. Band 4, \ 859-1089 ABGB, Wuch G, UN-Kaufrecht. 4. vyd. Wien: LexisNexis, 2014, \933a ABGB, marg. č. 5. Jak toto vyrovnání probíhá viz v podrobnostech MELZER, Filip. In: MELZER, Filip, Petr TÉGL et al. Občanský zákoník: velký

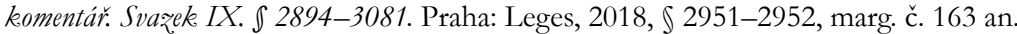

119 Viz KREJCI, Heinz. Reform des Gewährleistungsrechtes. Verlag Österreich, 1994, s. 108.

120 Podobně i v rámci německé diskuze SCHLINKER, Steffen. Sachmängelhaftung bei gemischter Schenkung: - Aktuelle Fragen nach der Reform des Schuldrechts. Archiv für die civilistische Praxis. Tübingen: Mohr Siebeck, 2006, 206. Band, H.1 (2006), s. 48. 
na náhradu nákladů je přitom dán v té míře, v jaké plnění zcizitele přesahuje vyrovnání narušené subjektivní ekvivalence. Uplatněním práva na odstranění vady a její následné provedení je tak třeba kvalifikovat jako konkludentní (příp. výslovné) uzavření bezúplatné př́kazní smlouvy. Jestliže př́kazní smlouva nevznikne (např. pro nedostatek zastoupení, svéprávnosti či duševní poruchy jedné ze stran) a zcizitel vadu přesto na základě žádosti nabyvatele odstraní, vzniká zciziteli provedením putativního prŕkazu (tj. odstraněním vady) kondikce vưči nabyvateli, konkrétně condictio indebiti (\$ 2991 odst. 2 alt. 1 OZ). Dle zde zastávaného názoru nelze akceptovat myšlenku, aby se aplikovala pravidla vnuceného obohacení ( $\int 3001$ odst. 2 alt. 2 OZ). ${ }^{121}$ Ten, kdo požaduje odstranění vady, si totiž je vědom, že mu bylo plněno v rámci smíšeného darování, a tedy částečně in causa donandi. Dovozování následku vnuceného obohacení není za těchto okolností slučitelné s požadavkem principu poctivosti (\$ () , zejm. s jeho aspektem v podobě zákazu venire contra factum proprium. Z doprovodných okolností však může plynout jiný závěr. Zda tedy nabyvatel souhlasil s odstraněním vady za podmínek, že zciziteli vznikne nárok na vynaložené vícenáklady, je třeba posuzovat dle $\int 556 \mathrm{OZ}$ a při zohlednění principu poctivosti.

Pr. č. 3: Bezvadná véc v hodnotě 100 (objektivni ekvivalence) má pro strany hodnotu 120 (subjektivni ekvivalence), pričemž prostrednictvím jediné smlouvy je věc z.poloviny své hodnoty darována a z. drubé prodána. $V$ duisledku vady má objektivni hodnotu 40. Prostrednictvim opravy, jejíz náklady čini 60, získá hodnotu 80. Nabyvatel požaduje po ziciziteli opravu véci.

Bude-li v daném př́padě věc opravena, pak bude mít hodnotu $80 \%$ bezvadného stavu. Nabyvatel za věc však poskytl úplatu v rozsahu $50 \%$ a zcizitel je povinen k nápravě vad v míre plněné oproti ekvivalentu (tj. ze 40 na 50). Odstranění vady, které se týká i části plnění poskytnuté bez ekvivalentu (tj. z 50 na 80), musí být zciziteli kompenzováno, nebot' $\mathrm{v}$ tomto rozsahu jej povinnost $\mathrm{z}$ vad netíží. Opačný závěr by negoval zájem bezúplatného zcizitele. Zcizitel tak je povinen $\mathrm{k}$ plnění z $1 \frac{1}{4}$, tj. vynaložit náklady ve výši 10, kdežto nabyvatel ve výši 30. Jinak řečeno, náklady na opravu věci zcizitel nese z $25 \%$, kdežto nabyvatel ze $75 \%$. Akceptuje-li zcizitel žádost nabyvatele o opravu věci, pak v důsledku privativní novace vzniká právní poměr z bezúplatné prríkazní smlouvy. Provedení opravy vady následně zakládá zciziteli (př́kazníku) nárok na účelně vynaložené náklady ze $75 \%$ ceny opravy, resp. jej opravňuje požadovat zálohu. Činí-li tak náklady na opravu celkem 60, pak zcizitel nese 15 (tj. $25 \%$ z 60), kdežto nabyvatel 45 (tj. $75 \%$ z 60).

Ve výše uvedeném př́kladě č. 3 by se mohlo zdát podivné, že se v nich nepromítá aspekt subjektivní ekvivalence. Tyto pochyby jsou však liché, nebot' při způsobu výpočtu je pracováno s objektivními hodnotami. K výsledku lze ostatně dojít i přes poměry subjektivní ekvivalence. Vadné plnění má totiž z hlediska subjektivní ekvivalence hodnotu 48,

121 Myslitelný je ale př́pad, kdy nabyvatel výslovně zciziteli projeví vưli, že nehodlá cokoliv za provedení opravy platit. Pak přichází v úvahu toliko přměřené snížení ceny, nejsou-li dány předpoklady odstoupení od smlouvy. 
přičemž oprava vady by zvýšila jeho hodnotu z hlediska subjektivní ekvivalence na 96. Odpovědnost za vady se týká jen rozsahu 48-60 (tj. 12), kdežto v rozmezí 60-96 (tj. 36) jde již o rozsah, kde odpovědnost nemá být dána. I zde dospějeme ke stejnému poměru, tj. 12:36 (1:3). Výsledek tedy bude tentýž: zcizitel nese 1/4 nákladů na opravu.

Konečně je třeba zmínit i řešení, k nimž dospívají jiné teorie. Přístup posuzující smíšené darování dle těžiště smlouvy také připouští odstranění vady (opravu věci), leč konsekventně neposkytne zciziteli částečný nárok na náhradu nákladů. ${ }^{122}$ Uplatnění práv z vad pochopitelně předpokládá, že smíšené darování je v jádru kvalifikováno jako koupě (či jiný úplatný zákonný smluvní typ). Po právu se tomuto př́istupu vytýká, že vede $\mathrm{k}$ neuspokojivému řešení „,všechno nebo nic“. ${ }^{123}$ Je-li totiž jako těžiště právního poměru kvalifikováno darování, tak neobdrží nabyvatel ničeho, ač poskytl částečný ekvivalent.

Teorie oddělení je absolutně nepoužitelná, nebot' vady nelze prriřazovat k ideálním podílům (viz výše). Pracovat s ní lze až tehdy, kdyby jako zde zastávaný názor navíc vyžadovala pokles hodnoty pod ekvivalentní část.

\subsubsection{Dodáni toho, co chybi}

Dodání chybějícího jako prostředek nápravy vadného plnění slouží k odstranění vad v kvantitě. ${ }^{124}$ Zpochybňována bývá jeho využitelnost u tzv. nepravých vad kvantity, jež se vyznačují nedostatkem míry, váhy či jiné kvantitativní vlastnosti individuálně určené věci (např. váha konkrétně prodaného prasete, množství zboží v konkrétně prodaném skladě etc.). Svou povahou totiž nejde o vadu v kvantitě, nýbrž o vadu v kvalitě. ${ }^{125}$ I přesto však některé nepravé vady v kvantitě mohou být odstraněny prostřednictvím pozdějšího dodání (např. zboží může být prodávajícím do skladu doplněno). ${ }^{126}$

Dle zde zastávaného názoru je proto třeba dále rozlišovat, zda vada je odstranitelná pozdějším dodáním (pak jde o vadu napravitelnou dodáním toho, co chybî), nebo

122 Viz CHIUSI, Tiziana J. In: MARTINEK, Michael (red.). J. von Staudingers Kommentar zum Bürgerlichen Gesetzbuch. Buch 2, Recht der Schuldverbältnisse. \516-534 (Schenkungsrecht). Berlin: Sellier-de Gruyter, 2013, \516, marg. č. 84; podobně též OECHSLER, Jürgen. Vertragliche Schuldverbältnisse. 2., přepracované vyd. Tübingen: Mohr Siebeck, 2017, marg. č. 681; GEHRLEIN, Markus. In: HAU, Wolfgang, Roman POSECK et al. Beck'sche Online Kommentar BGB. Stav: 56. Ed. 1. 11. 2020. Dostupné z: Beck-online.de. BGB, \516, marg. č. 17.

123 Viz KOCH, Jens. In: WESTERMANN, Harm Peter et al. Münchener Kommentar zum Bürgerlichen Gesetzbuch. Band 4. Schuldrecht - Besonderer Teil I $\int 433-534$ Finanzierungsleasing CISG. 8. vyd. München: C. H. Beck, 2019, BGB, \516, marg. č. 44.

124 Viz KREJCI, Heinz. Reform des Gewährleistungsrechtes. Verlag Österreich, 1994, s. 91.

125 Viz Ibid., s. 96, pozn. pod čarou č. 172; PISKO, Oskar. Gewährleistungs-, Nichterfüllungs- und Irrtumsfolgen bei Lieferung mangelhafter Ware. 2. přepracované. vyd. Wien: Verlag von Moritz Perles, 1926, s. 86 a násl.

126 Někteři autoři připouští pro nepravé vady $\mathrm{v}$ kvantitě pouze přiměřenou slevu z ceny (takto Welser, FS Strasser 924 ff. Cit dle KREJCI, Heinz. Reform des Gewährleistungsrechtes. Verlag Österreich, 1994, s. 99, pozn. pod čarou č. 176; shodně též KANDUT, Gabriele. Das Gewährleistungsrecht beim Kauf. Österreichische Staatsdruckerei, 1992, s 83). 
odstranitelnou skrze zásah do substance věci (pak jde o vadu odstranitelnou opravou věci), event. neodstranitelnou ani jedním způsobem (pak přichází v úvahu přiměřená sleva z ceny, příp. za splnění dalších podmínek odstoupení od smlouvy). ${ }^{127}$

Zmíněný prostředek nápravy opět nečiní obtíže tam, kde lze využít teorie o mnohosti smluv (viz 3.1), nebo je-li dodáním chybějícího vyrovnána narušená subjektivní ekvivalence, aniž by dárce plnil nad tento rámec. Má-li však zcizitel dodáním toho, co chybí narovnat více, než činí míra narušené subjektivní ekvivalence, uplatní se závěry vyslovené ve vztahu k opravě věci (viz 6.2.1). Z toho důvodu i zde privativní novací vzniká zciziteli částečný nárok na náhradu vynaložených nákladů, resp. právo požadovat jejich zálohu dle \2436 OZ.

\subsection{Přiměřené snížení ceny}

Přiměřené snížení ceny (přiměřená sleva z ceny) se pokládá za univerzální prostředek nápravy, tedy použitelný bez ohledu na to, zda je vada odstranitelná, či neodstranitelná (srov. \1923 OZ). ${ }^{128}$

Uplatnitelnost přiměřené slevy z ceny se bude odehrávat taktéž dle pravidel zmíněných sub 4, 5. I zde má být aplikována tzv. relativní početní metoda. ${ }^{129}$ Využití poměru objektivních hodnot však nebude vycházet z obvyklé ceny celé věci, nýbrž z obvyklé ceny části, za kterou byl poskytnut ekvivalent. Opačně nelze dospět k uspokojivému výsledku, jenž by respektoval zájmy obou stran.

Pr. č. 4. Vèc v objektivni hodnotě 100 (objektivni ekvivalence) si strany ceni na 120 (subjektivní ekvivalence). Z poloviny hodnoty je věc darována, kdežto z drubé koupena. Na véci lpi vada, $v$ düsledku čehož má objektivní hodnotu pouze 40.

Zde si je třeba uvědomit, že dle smluvních ujednání za objektivní hodnotu věci ve výši 50 platí nabyvatel 60. Činí-li hodnota vadné věci jen 40, pak nelze vyjít z převládajícího názoru české literatury a judikatury, tedy dospět k závěru, že částka má být snižována o 10 s odůvodněním, že škoda zpơsobená vadným plněním na majetku nabyvatele je 10 (tj. 50 - 40). ${ }^{130}$ Naopak je třeba vyjít ze zachování subjektivní ekvivalence v úplatné části, tudíž zachovat nevýhodnost koupě. Má-li věc z hlediska úplatné části o pětinu nižší

127 Takto ve výsledku i KREJCI, Heinz. Reform des Gewährleistungsrechtes. Verlag Österreich, 1994, s. 100.

128 Podobně stanoví i pravidla o koupi věci movité (srov. \2107 odst. 1 alt. 2 OZ) a zvláštní ustanovení o prodeji zboží v obchodě (\ 2169 odst. 3 OZ).

${ }^{129} \mathrm{~K}$ bližšímu odůvodnění a vč. dalších odkazů KOLMAČKA, Viktor. Přiměřené snížení ceny jako prostředek nápravy narušené subjektivní ekvivalence. Právní roz̧bledy. roč. 29, č. 13-14, sub V.2, s. 463-465.

130 Takto LAZAR, Ján a Jiř́ ŠVESTKA. Občanské právo hmotné. 2. Praha: Panorama, 1987, s. 240-241; viz též rozsudek Nejvyššího soudu ze dne 26. 5. 2010, sp. zn. 23 Cdo 1299/2008. V podrobnostech vč. argumentace srov. komplexní rozbor in KOLMAČKA, Viktor. Přiměřené snížení ceny jako prostředek nápravy narušené subjektivní ekvivalence. Právní roz̧bledy. roč. 29, č. 13-14, s. 457-468. 
hodnotu, než mít měla, musí být rovněž úplata o pětinu nižší. ${ }^{131}$ Přiměřená sleva z ceny proto musí činit 12 , nikoliv $10 .^{132}$

Naproti tomu dle teorie jednoty je přiměřená sleva z ceny vyloučena, nebot' ,je nespravedlivé, pokud si dárce musi nechat líbit ještě dalši sniženeni ceny" "133 Podobný, nikoliv shodný, prústup jako zde zastávaný byl př́żnačný i pro autory, kteří stavěli na dělící nauce. Dospívali totiž k závěru, že snížení ceny není možné, pokud hodnota vadné věci neklesne pod hodnotu poskytnutého protiplnění. ${ }^{134} \mathrm{~K}$ naposledy uvedenému prŕstupu se přiklání i někteří soudobí autoři, ${ }^{135}$ jež za rozhodující kritérium označují, zda sjednaná kupní cena přesahuje hodnotu vadné věci. Protože objektivní ekvivalence není dle zde zastávaného názoru určující (preferována je subjektivní ekvivalence), pak se zde tomuto názoru nepřitakává. Vztaženo k naposledy uvedenému př́kladu (tj. č. 4) tedy nepostačí, pokud věc nemá alespoň objektivní hodnotu 60, nýbrž alespoň 50. Argument, že s ohledem na altruistický motiv zcizitele je třeba vycházet z objektivní hodnoty, ${ }^{136}$ nepřesvědčí, nebot' nedůvodně je upozaděna causa adquirendi a požadavek subjektivní ekvivalence.

\subsection{Odstoupení od smlouvy}

Konečně poslední právo z vad představuje odstoupení od smlouvy. Jmenované právo předpokládá nejen neodstranitelnost vady, ale současně též to, že předmět plnění nelze řádně užívat (\1923 v. 2 OZ). Naproti tomu dle ustanovení o koupi věci movité se přiznává kupujícímu i tehdy, kde vadné plnění lze kvalifikovat jako podstatné porušení

131 Tak jako zde i CHIUSI, Tiziana J. In: MARTINEK, Michael (red.). J. von Staudingers Kommentar zum

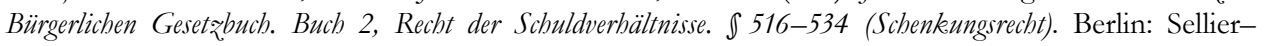
de Gruyter, 2013, \516, marg. č. 84. Podobně i rak. nauka, byt' výslovně nezdưrazňuje, že je rozhodující subjektivní ekvivalence, nikoliv objektivní (viz EHRENZWEIG, Armin a Josef KRAINZ. Der allgemeine Teil und das Sachenrecht. 5. zcela přepracované vyd. Wien: Manzsche k. u. k. Hof-Verlags- und UniversitätsBuchhandlung, 1913, s. 327; shodně WELSER, Rudolf a Brigitta ZÖCHLING-JUD. Bürgerliches Recht II. 14. vyd. Wien: Manz, 2015, marg. č. 863; ERTL, Gunter. In: FENYVES, Attila, Ferdinand KERSCHNER, Andreas VONKILCH et al. Großkommentar zum ABGB - Klang Kommentar. $\int 938$ bis 1001. 3. vyd. Wien: Verl. Österreich, 2013, \938, marg. č. 45; shodně BOLLENBERGER, Raimund. In: KOZIOL, Helmut, Peter BYDLINSKI, Raimund BOLLENBERGER et al. Kurzkommentar zum $A B G B$. vyd. 3. Wien: Springer, 2010, $\int 940$, marg. č. 8).

132 Výpočet přes relativní početní metodu vypadá následovně: 50/60 $=40 / \mathrm{x} \rightarrow \mathrm{x}=48$; sleva tak činí 12 (tj. 60 - 48).

133 Takto MÜLLER, Wilhelm. Die gemischte Schenkung. Jherings Jahrbücher für die Dogmatik des bürgerlichen Rechts. Band 48. Jena: Fischer, 1904, s. 229; jej následuje GOLDSCHMIDT, Siegfried. Die gemischte Schenkung nach Reichsrecht. Berlin: Verlag von Struppe \& Winckler, 1907, s. 59.

134 Takto ZIEGLER. Die gemischte Schenkung. Diss. jur. Leipzig, Dresden, 1937, s. 24, 41. Cit dle SCHLINKER, Steffen. Sachmängelhaftung bei gemischter Schenkung: - Aktuelle Fragen nach der Reform des Schuldrechts. Archiv für die civilistische Praxis. Tübingen: Mohr Siebeck, 2006, 206. Band, H. 1 (2006), s. 49.

135 Ibid.; shodně KOCH, Jens. In: WESTERMANN, Harm Peter et al. Münchener Kommentar zum Bürgerlichen Gesetz̧buch. Band 4. Schuldrecht-Besonderer Teil I I 433-534 Finanzierungsleasing CISG. 8. vyd. München: C. H. Beck, 2019. Dostupné z: Beck-online.de. BGB, \516, marg. č. 45.

136 Ibid. 
smlouvy (〔 2106 odst. 1 písm. d] OZ), přičemž vada může být odstranitelná. ${ }^{137}$ Požadavek hodnotově koherentního výkladu se musí plně prosadit i v tomto prostředku nápravy vadného plnění, poněvadž neexistuje věcný důvod k odlišnému právnímu zacházení. Právo odstoupit od smlouvy tak musí zakládat vada, která ohrožuje v obou př́padech zájmy nabyvatele stejným způsobem. ${ }^{138}$

Nelze přitakat přístupu, aby v rámci kupní smlouvy bylo možno za využití \ 2002 odst. 1. v. 2 OZ kvalifikovat odstranitelnou vadu jako podstatné porušení smlouvy a umožnit odstoupení od smlouvy, přičemž v obecné části závazkového práva se trvalo na předpokladech \1923 v. 2 OZ (tj. na neodstranitelnosti vady). Zde je prima facie zjevná vnitřní inkonzistence úpravy následků vadného plnění. Požadavek hodnotově koherentního př́stupu musí převážit nad odlišnou textací pravidel, $\mathrm{k}$ níž neexistuje věcný důvod. Z důvodu obecného přesahu, který pruímo není odvislý od povahy smíšeného darování, se tato otázka zde nezodpovídá. ${ }^{139}$

Sporné je, zda i odstoupení od smlouvy se musí odehrávat dle pravidel uvedených sub 4, 5 . Podle panující německé ${ }^{140}$ a rakouské ${ }^{141}$ nauky, kde odstoupení od smlouvy má pouze

137 Tato skutečnost se podává $z$ toho, že i při vadě představující podstatné porušení lze dle $\$ 2106$ odst. 1 písm. b) OZ požadovat opravu věci.

138 Celá tato potíž je však způsobena slepeností různých právních úprav, nejprve pravidel z ABGB ovlivněné vývojem českého práva (\$1914 an.), úpravou v CISG, převzaté do ObchZ (\$ 2099 an. OZ) a konečně směrnicovou úpravou (ustanovení o zboží v obchodě, tedy $\ 2165$ an). Každá z nich stojí na poněkud odlišných koncepcích, které se vyznačují různými vztahy a předpoklady jednotlivých prostředků nápravy vad.

${ }^{139} \mathrm{Na}$ margo se uvádí, že veskrze podobný problém se vyskytoval i v ABGB. Dle obecných ustanovení bylo možné odstoupit od smlouvy (přesněji tzv. Wandelung) jen tehdy, byla-li vada neodstranitelná a (současně!) bránila-li řádnému užití věci (\$932 ABGB ve znění účinném do 31. 12. 2001). Naproti tomu u smlouvy o dílo (\$1167 ABGB ve znění účinném do 31. 12. 2001) bylo právo odstoupit od smlouvy podmíněné „podstatnou vadou“ (wesentlicher Mangel), ač mohlo jít o vadu odstranitelnou. OGH odůvodňoval tento rozkol tak, že zhotovitel není pouze tím, s kým objednatel jedná, nýbrž též tím, kdo věc vyrábí; objednatel proto smí být skeptičtější stran schopností zhotovitele vadu odstranit oproti prodávajícímu (srov. rozhodnutí OGH ze dne 2. 10. 1930, sp.zn. 3 Ob 447, publik. v časopise Österreichisches Zentralblatt für die juristische Praxis, roč. 1931, rozhodnutí č. 197, s. 593-594). Přiléhavá je poznámka Krejciho, že postavení prodávajícího a zhotovitele se v tomto př́ípadě neliší (KREJCI, Heinz. Reform des Gewährleistungsrechtes. Verlag Österreich, 1994, s. 82, 88). Citovaný autor uvádí, že je-li narušen vztah důvěry nabyvatele a nelze-li po něm spravedlivě požadovat, aby dal zciziteli druhou šanci, pak by u species měl mít nabyvatel právo odstoupit od smlouvy i dle obecné části. Řešení tak vidí v zobecnění zvl. pravidla u smlouvy o dílo (Ibid., s. 82-83). U věcí určených in genere je prodávající vždy schopen vadu odstranit, ledaže jde o vadu stíhající celý druh (Ibid., s. 83). Krejci tedy navrhoval částečné zobecnění pravidla o odstoupení od smlouvy pro odstranitelnou vadu (Ibid., s. 83). Představené problémy sice již v důsledku novel ABGB zavál čas, přesto však při řešení českých sporných otázek mohou sehrát inspirativní roli.

140 Srov. KOCH, Jens. In: WESTERMANN, Harm Peter et al. Münchener Kommentar zum Bürgerlichen

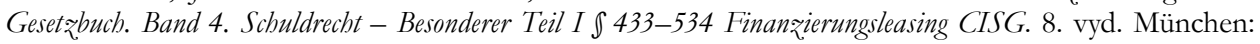
C. H. Beck, 2019. In: Beck-online.de, BGB, \516, marg. č. 45.

141 Srov. EHRENZWEIG, Armin a Josef KRAINZ. Der allgemeine Teil und das Sachenrecht. 5. zcela přepracované vyd. Wien: Manzsche k. u. k. Hof-Verlags- und Universitäts-Buchhandlung, 1913, s. 327; ERTL, Gunter. In: FENYVES, Attila, Ferdinand KERSCHNER, Andreas VONKILCH et al. Großkommentar zum $A B G B$ - Klang Kommentar. $\int 938$ bis 1001. 3. vyd. Wien: Verl. Österreich, 2013, \938, marg. č. 45; shodně BOLLENBERGER, Raimund. In: KOZIOL, Helmut, Peter BYDLINSKI, Raimund BOLLENBERGER et al. Kurækommentar zum ABGB. vyd. 3. Wien: Springer, 2010, \$ 940, marg. č. 8. 
obligační účinky a zakládá nárok na vrácení plnění, vede odstoupení od smlouvy k ukončení a vypořádání celého závazku, nebot’ smíšené darování vytváří nedělitelnou jednotu. Jinými slovy, požadavek vyrovnání narušené subjektivní ekvivalence se neuplatní (sub 5). $K_{o c h}{ }^{142}$ přitom nevyžaduje dokonce ani to, aby vada vedla k narušení ekvivalence, ergo nemá se ani uplatnit teze uvedená sub $4 .{ }^{143}$ Údajně je tomu tak proto, že nabyvatel musí mít možnost vyvázat se ze smlouvy, která mu sice nepůsobí újmu, ale přes tuto podmínku by smlouvu neuzavřel. Zde se poznamenává, že takové odůvodnění se z důvodu \ 1923 v. 2 OZ nejeví jako plauzibilní, poněvadž odstoupení od smlouvy není vázáno na podstatné porušení smlouvy (srov. ale výše vytýkaný hodnotový rozpor). ${ }^{144}$

Podaný přístup koncepčně neodpovídá převládajícímu názoru české nauky, dle něhož odstoupení od smlouvy má věcněprávní účinky ex tunc (viz výše). Stavíme-li nekriticky na těchto poznatcích, pak výkonem práva odstoupit od smlouvy se zásadně nabyvatel stává se zpětnými účinky prrímo vlastníkem poskytnutého protiplnění a zcizitel naopak zase vlastníkem předmětu plnění. Nyní se však klade otázka, zda se věcněprávní účinky odstoupení od smlouvy mají omezit jen na část vyváženou ekvivalencí, nebo se vztahuji k celému plnění, tedy vč. darované části. V prvním případě by byl nevyhnutelným následkem vznik spoluvlastnictví, což někteří označují za dogmaticky nečisté a nesmyslné řešení, ${ }^{145}$ příp. též za neuspokojivé, ${ }^{146}$ nebot' by se podíl nabyvatele musel přeměnit v nárok na peněžní vypořádání. Ve druhém prrípadě by byl v podstatě sledován prezentovaný prrístup zahraniční nauky, prričemž by bylo třeba celý závazek vypořádat přes pravidla o bezdůvodném obohacení.

Pr. č. 5: Vèc v objektivni hodnotě 100 (objektivni ekvivalence) si strany ceni na 120 (subjektivní ekvivalence). Z poloviny hodnoty je věc darována, z drubé koupena. Na véci lpi vada, pričemž. objektivni hodnota věci tak činí pouze 40. Vada je neodstranitelná a brání v rádném ư̌iváni véci.

Dle prvního př́stupu odstoupením od smlouvy vzniká k předmětu plnění spoluvlastnictví, přičemž zcizitel se se zpětnými účinky stává vlastníkem ideální poloviny věci a nabyvateli zůstává druhá ideální polovina. Zcizitel musí navíc vrátit obdrženou úplatu (bud' je dán vindikační, nebo kondikční nárok). Zcizitel by tak ve své podstatě zůstal zavázán

142 Takto KOCH, Jens. In: WESTERMANN, Harm Peter et al. Münchener Kommentar zum Bürgerlichen Gesetzbuch. Band 4. Schuldrecht - Besonderer Teil I I 433-534 Finanziierungsleasing CISG. 8. vyd. München: C. H. Beck, 2019. Dostupné z: Beck-online.de. BGB, \516, marg. č. 45.

143 Z výše citované rakouské literatury není zcela zřejmé, zda i zde staví na subjektivní ekvivalenci.

144 Myslitelná je konstrukce toto právo rozšírit přes $\int 2002$ v. 1 OZ. Tímto způsobem lze pak odstranit výše zmiňovaný nesoulad obecné úpravy z vad a úpravy v rámci koupi věci movité. První př́pad totiž neumožňuje odstoupení od smlouvy, je-li vada odstranitelná, druhý však ano.

145 Tak SCHLINKER, Steffen. Sachmängelhaftung bei gemischter Schenkung: - Aktuelle Fragen nach der Reform des Schuldrechts. Archiv für die civilistische Praxis. Tübingen: Mohr Siebeck, 2006, 206. Band, H. 1 (2006), s. 49.

146 Tak GOLDSCHMIDT, Siegfried. Die gemischte Schenkung nach Reichsrecht. Berlin: Verlag von Struppe \& Winckler, 1907, s. 29. 
jako dárce. Dle druhého prŕístupu získá zcizitel zpět vlastnické právo k celé věci, přičemž musí vrátit pouze úplatu.

Z doposud podaného je patrno, že první přístup, dle něhož vzniká spoluvlastnictví a který je př́iznačný pro úvahy stojící na dělící nauce, ${ }^{147}$ vede k tomu, že zcizitel, event. nabyvatel bude muset $\mathrm{z}$ důvodu vzniku spoluvlastnictví a v důsledku jeho následného vypořádání poskytnout druhé smluvní straně peněžní ekvivalent za její podíl. Nutno podotknout, že vypořádání by se v této situaci neodehrávalo dle subjektivní ekvivalence (ta je pro vypořádání spoluvlastnictví bez významu [srov. \1140 an. OZ]), nýbrž dle objektivních hodnot. Takový postup by zpravidla vedl ke zjevnému odcizení od stranami chtěného záměru.

Naproti tomu u druhého př́stupu nabyvatel přichází i o tu „pomyslnou“ část plnění, jež byla poskytnuta in causa donandi, a nezůstává mu tak ani spoluvlastnický podíl. Causa donandi se tu přesouvá do pozadí. Na druhou stranu je ale třeba mít na paměti, že obě kauzy jsou úzce provázané a v řadě př́padů nebude možno dospět k závěru, že by zcizitel věc daroval i tehdy, jestliže by ani za část její hodnoty nezískal ekvivalent, ledaže jsou splněny předpoklady využití absorpční metody (viz 3.7). Takové založení spoluvlastnického práva však v řadě prrípadů nebude odpovídat (hypotetické) vưli stran, protože strany by bývaly nechtěly založit „přinejmenším“ spoluvlastnictví. Občanský zákoník sice nepamatuje žádným výslovným pravidlem na provázané kauzy, nicméně akceptuje institut tzv. závislých smluv (\$ 1727 OZ), jenž z provázanosti kauz vychází. Na základě této zákonem akceptované hodnoty lze pak prostřednictvím doplňujícího výkladu vytvořit obdobné pravidlo i pro prrípad odstoupení od smlouvy u smíšeného darování.

Zde zastávaný názor se kloní tedy ke druhému přístupu (tj. že odstoupení vede k zániku celého závazku), nebot’ lépe reflektuje provázanost dvojí kauzy. Vytvoření spoluvlastnického vztahu by představovalo dalekosáhlé odcizení hypotetické vůli stran. Zájem nabyvatele je prítom hájen tím, že není nucen uplatnit odstoupení od smlouvy a vždy může využít právo na přiměřené snížení ceny. Z toho důvodu lze vyjít analogicky z právního následku \ 1727 v. 3 OZ. Projeví-li však strany jinou vůli, je třeba tuto skutečnost vzít v potaz při výkladu práva odstoupení od smlouvy a zvážit i vznik spoluvlastnictví (např. dvougenerační dům je jedinou smlouvou převeden z půlky hodnoty in causa donandi, $z$ druhé in causa adquirendi).

Nelze přitakat závěru, že vada nemusí vést k narušení ekvivalence (tj. že v př̀. č. 5 nemusí vada věci představovat poklesnutí objektivní hodnoty věci pod 50). Tento př́stup si totiž neuvědomuje, že pro práva z vad není rozhodující podstatné porušení smlouvy, nýbrž narušení ekvivalence. Jestliže tak ekvivalence není narušena, ale i přesto jde o podstatné porušení (dárce by dar nepřijal), pak nelze opřít právo odstoupení od smlouvy o \ 1923 v. 2 OZ, ledaže by bylo ujednáno jinak.

147 Viz Ibid., s. 28. 


\section{Závěr}

Výše uvedené stěžejní závěry lze shrnout do těchto dílčích metazávěrů:

- Odpovědnost zcizitele za vadné plnění je prostředkem nápravy narušené subjektivní ekvivalence stran (1.1), která ze své podstaty u lukrativních smluvních typů absentuje (1.2).

- O smíšené darování jde jen tehdy, jestliže smluvní poměr stojí na duplicitní kauze, a to causae donandi a causae adquirendi, nikoliv jen na značném objektivním nepoměru plnění (2). Smíšené darování je proto inominátní smlouvou (též smlouvou sui generis), přičemž prostřednictvím úvah imanentních doplňujícímu výkladu je třeba zprostředkovat pravidla, která se na takovou smlouvu použijí (3.7).

- Pro nabyvatelova práva z vad, jemuž bylo plněno současně in causa donandi a in causa adquirendi, se jako conditio sine qua non vyžaduje narušení subjektivní ekvivalence. Ekvivalence je přitom narušena tehdy, kdy na předmětu plnění lpí vada, v důsledku které má předmět plnění nižší hodnotu, než za kterou bylo nabyvatelem poskytnuto protiplnění (4). Povinnost zcizitele se uplatní jen v té míře, v jaké je narušena subjektivní ekvivalence (5).

- Pravidla vymezující vadné plnění, stejně tak jako pravidla regulující jejich uplatnění se použijí na smíšené darování per analogiam (6.1).

- Jak oprava věci, tak dodání chybějícího se uplatní dle předpokladů a v míře uvedené sub 4 a 5 . Dohodne-li se nabyvatel a zcizitel na odstranění vady, které přesáhne prostou nápravu narušené subjektivní ekvivalence, jde o privativní novaci, nebot' namísto uplatněného práva $z$ vad nastupuje právní poměr z bezúplatné příkazní smlouvy. Zciziteli (př́kazníku) vznikne dle \2436 OZ nárok na náhradu nákladů, event. právo požadovat zálohu, a to však jen v tom rozsahu, v jakém budou náklady na odstranění vady přesahovat narušenou subjektivní ekvivalenci. Totéž platí mutatis mutandis pro dodání chybějícího (6.2).

- Přiměřené snížení ceny se odehrává exaktně za podmínek sub 4 a 5 (6.3).

- Odstoupení od smlouvy pro vady je možné jen za předpokladu sub 4, přičemž jeho následkem je kompletní vypořádání smluvního poměru, nebot' obě kauzy jsou na sobě závislé (6.4). 